\title{
A physiological and biochemical approach to selecting the ideal diet for Ostrea edulis (L.) broodstock conditioning (part A)
}

\author{
Ricardo González-Araya ${ }^{1,2}$, Isabelle Quéau ${ }^{1}$, Claudie Quéré ${ }^{3}$, Jeanne Moal ${ }^{3}$, René Robert ${ }^{1,{ }^{*}}$
}

${ }^{1}$ IFREMER, UMR 100 Physiologie et Ecophysiologie des Mollusques Marins, Station Expérimentale d'Argenton, Ecloserie Expérimentale d'Argenton, Argenton en Landunvez, France

${ }^{2}$ Departamento de Acuicultura y Recursos Acuáticos, Universidad de Los Lagos, Osorno, Chile

${ }^{3}$ IFREMER, UMR 100 Physiologie et Ecophysiologie des Mollusques Marins, Centre de Brest, Plouzané, France

*: Corresponding author : R. Robert, email address : Rene.Robert@ifremer.fr

\begin{abstract}
:
To select the best microalgae for Ostrea edulis conditioning, four single species diets were fed to batches of broodstock, which were then compared using physiological and biochemical approaches. Ingestion and absorption were first studied, showing that Chaetoceros gracilis and Skeletonema marinoï were efficiently ingested $\left(4.9-5.3 \mathrm{mg} \mathrm{g}^{-1} \mathrm{~h}^{-1}\right)$ and absorbed $\left(1.9-2.5 \mathrm{mg} \mathrm{g}^{-1} \mathrm{~h}^{-1}\right.$ ) while Tetraselmis suecica led to the lowest physiological responses (0.36 and $0.12 \mathrm{mg} \mathrm{g}^{-1} \mathrm{~h}^{-1}$ respectively). When $O$. edulis were fed any microalgae except T-ISO with only $79 \mathrm{mg} \mathrm{g}^{-1}$, gonads accumulated carbohydrates from 116 to $141 \mathrm{mg} \mathrm{g}^{-1}$ and the extent of accumulation depended on the species supplied in the order $T$. suecica $<C$. gracilis $<S$. marinoï. When oysters were fed either of the diatoms (C. gracilis or S. marinoi), an efficient transfer of 20:5(n-3) to all tissues, including the gonads, was recorded while no enrichment in 22:6(n-3) occurred in all tissues (polar fraction) when oysters were fed T-ISO. In contrast (22:5(n-6)), a characteristic fatty acid of T-ISO accumulated in all tissues, confirming its allocation despite particularly low ingestion $\left(1.66 \mathrm{mg} \mathrm{g}^{-1} \mathrm{~h}^{-1}\right)$ and absorption $\left(0.32 \mathrm{mg} \mathrm{g}^{-1} \mathrm{~h}^{-1}\right)$. When oysters were fed $C$. gracilis or $\mathrm{S}$. marinoï an efficient transfer of cholesterol and campesterol from diatoms to the gonads was observed, while no sterol accumulation occurred in the gonad when fed $T$. suecica. Because of low ingestion, absorption and poor biochemical compounds' transfer, $T$. suecica is not recommended for $O$. edulis conditioning. T-ISO also exhibited low physiological performances but due to a specific 22:6(n-3) enrichment in the gonad neutral fraction $(16.1 \%)$, its potential role in reproduction should be considered. Chaetoceros gracilis is highly recommended for $O$. edulis broodstock while a source of DHA other than that provided by T-ISO should be found due to its poor absorption. Because a mixed diet has been shown to be more efficient for $O$. edulis broodstock conditioning, complementary trials dealing with the effects of other species rich in 22:6(n-3) such as Rhodomonas salina or Pavlova lutheri should be performed.
\end{abstract}

Keywords: Ostrea edulis, conditioning, algal diets, ingestion, absorption, biochemical composition 


\section{Introduction}

The flat oyster Ostrea edulis held a dominant position in European shellfisheries from 1950 to 1980, and was accordingly the main biological model studied by Walne in Conway (UK), one of the pioneers of the hatchery rearing techniques (Walne 1966; Walne 1970). A tremendous amount of work was done during this period (see papers in Walne 1974) but since the appearance of diseases due to Marteilia refringens (Comps 1970) and Bonamia ostreae (Comps et al. 1980) in France, and the extension of the latter across Europe (e.g. Holland: van Banning 1990, Spain: Montes et al. 1991, Ireland: Culloty \& Mulcahy 1996) such specific hatchery knowledge has progressively declined.

However, the production demand for hatchery-produced juveniles is predicted to increase significantly for many mollusks, due either to genetic improvement through selection (Ward, et al. 2000; King et al. 2004) or due to a decline in natural stocks (Laing et al. 2005). Moreover, the French oyster industry relied on monoculture (130 000 tonnes year- ${ }^{1}$ of Crassostrea gigas), which is nowadays impeded by severe juvenile mortality (Samain \& McCombie 2008; Pernet et al. 2010). There is accordingly a need to diversify shellfish production in France and flat oyster cultivation enjoys renewed interest.

The control of reproduction is the first step in mollusk hatchery management (Utting \& Spencer 1991; Helm et al. 2004), in which temperature and food are known to play a major role. The effect of food on broodstock conditioning is species specific both in quantity and in quality (Utting \& Millican 1997). Thus, algal diets representing 3-6\% of the initial dry weight of $O$. edulis broodstock increaselarval production (Millican \& Helm1994) and low fecundity is reported when only fed Dunaliella tertiolecta. In $O$. edulis, reproductive effort is therefore high because the quality of food during conditioning will affect the growth and survival of larvae after their release (Walne 1970). There is little published work related to optimal algal size and algal densities in $O$. edulis broodstock conditioning. In contrast, more information is available on the nutritional requirements at different stages of development: broodstock (Frolov \& Pankov 1992), larvae (Ferreiro et al. 1990) and juvenile (Enright et al. 1986). Nevertheless, the relationship between broodstock feeding and larval development remains poorly known. On comparing broods of $O$. edulis larvae originated from a closely controlled hatchery conditioning regime (unfiltered seawater) and from mature oysters taken from a wild population, an increased level of 20:5(n-3) and 22:6(n-3) was observed from late June (Helm et al. 1991). In the hatchery, supplementary algal feeding improved fertility and larval development (Helm et al.

1973), but conflicting results were reported some years later (Millican \& Helm 1994). The latest report concluded that hatchery-conditioned broodstock showed lower fecundity than wild stock and pointed out that there remained considerable scope to improve broodstock maintenance. To fill this gap, an efficient broodstock diet was searched for by Berntsson et al. (1997). However, unfed O. edulis breeders released larvae that performed as well as those originated from fed parents. Moreover, a high variability in larval development achieved for the same food treatment made interpretation difficult (Berntsson et al. 1997). Today, < 10 algal species of the Bacillariophyceae (i.e. diatoms) and Haptophyceae are routinely cultured in commercial bivalve hatcheries (Coutteau \& Sorgeloos 1992; Robert et al. 2004). Microalgae are commonly used in multi-species diets, generally composed of one diatom and one or more flagellates, to ensure a better balance of essential nutrients (Robert \& Trintignac 1996; Brown et al. 1997). Although this practice is generally successful, mollusc feeding requirements are still poorly understood (Robert \& Trintignac1997; Knauer \& Southgate 1999;Volkman \& Brown 2006) and there is a crucial need for studies in this field. To be suitable for broodstock conditioning, a microalga must be well ingested, digested, assimilated and allocated efficiently to the reproductive compartment. The present study focuses on the ecophysiological aspects of feeding in $O$. edulis conditioned with four different microalgae, with a study of the biochemical allocation of these diets to differenttissues including the gonads. 


\section{Materials and methods}

\section{Broodstock conditioning}

In February 2008, O. edulis aged 18-months ( $\approx 5 \mathrm{~cm}$ length and $0.5 \mathrm{~g}$ meat dry weight), originating from Bay of Cancale (North Brittany, France) were distributed homogeneously, in translucent $50 \mathrm{~L}$ tanks (30 oysters per tank for an equivalent biomass). Triplicate tanks were set up for each of the four single species diets tested here. Seawater was maintained at 19 ${ }^{\circ} \mathrm{C}$ in a flow-through system at a flow rate of $12 \mathrm{~L} \mathrm{~h}^{-1}$, and the oysters were continuously fed at $900 \mu \mathrm{m}^{3} \mu \mathrm{L}^{-1}$ per feeding condition by means of a peristaltic pump. Seawater $\left(34 \mathrm{~g} \mathrm{~L}^{-1}\right)$ was filtered on $1 \mu \mathrm{m}$ polypropylene filter media following UV treatment. Four different microalgae were tested as mono-specific diets: Isochrysis affinis galbana (volumetric size $\approx 45 \mu \mathrm{m}^{3}$, dry weight $20 \mathrm{pg}$ cell $^{-1}$, T-ISO strain CCAP 927/14), Chaetoceros gracilis $\left(80 \mu^{3}, 70 \mathrm{pg} \mathrm{cell}^{-1}\right.$, strain UTEX LB2658), Skeletonema marinoï (85 $\mathrm{mm}^{3}, 50 \mathrm{pg}$ cell $^{-1}$, strain CCAP 1077/3) and

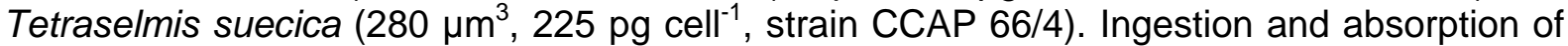
these different microalgae were studied according to Beiras et al. (1994) over six consecutive weeks. It was hypothesized that the microalgae species that was best absorbed by the oysters represented the best potential diet, so we tested this hypothesis by examining nutrient biochemical allocation to the gonads compared to other tissues.

\section{Culture of microalgae}

Microalgae were grown using a standard batch culture method (Robert et al. 2004). Actively growing starter cultures $(6 \mathrm{~L})$ were inoculated into Perspex translucent columns containing $300 \mathrm{~L}$ of $1 \mathrm{~mm}$ filtered seawater previously UV treated (salinity: $34 \mathrm{~g} \mathrm{~L}^{-1}$ ) enriched with Conwy media (Walne1966). Cultures were grown under continuous illumination (160 mmol photon $\mathrm{m}^{-2} \mathrm{~s}^{-1}$ ) at $21{ }^{\circ} \mathrm{C}$ and aerated with a $2 \% \mathrm{CO}_{2}$ /air mixture to maintain $\mathrm{pH}$ between 7.6 and 8.1. The cell count of cultures was monitored daily using a Mallasez haemocytometer (Batailler Labo, Treillères, France) or a Multisizer 3 (Beckman Coulter, Paris, France). Cultures attained the late-logarithmic phase after 3-5 days, at which time samples were removed for feeding to flat oysters and for biochemical analyses.

A minimum of three different cultures of individual algal species were used throughout each of the experiments.

\section{Ecophysiological data acquisition}

\section{Consumption and ingestion}

Algal concentration was determined twice a day using a coulter particles counter (Multisizer 3 ) at the inlet and outlet of each tank. In a flow-through culture system, algal consumption corresponds to: $\mathrm{C}=(\mathrm{Ci}-\mathrm{Co})$ * flow, where $\mathrm{Ci}$ is the food concentration of the incoming seawater and $\mathrm{Co}$ is food concentration of the outgoing seawater. $\mathrm{C}$ was expressed in $\mathrm{mg}$ (dry weight algae) per g (dry weight of oyster meat) per hour. In most molluscs, some of the filtered particles may be rejected as pseudofaeces. In this case ingestion is defined as: I = CPF, where PF is the amount of pseudofaeces. Because pseudofaeces production corresponds to an energetic loss for the animal it should be reduced as much as possible to optimize conditioning efficiency. Preliminary trials were accordingly run on two single diets TISO and C. gracilis and showed that food delivery should be reduced to $4.5 \%$ dry weight $\mathrm{g}^{-1}$ 
of oyster to induce only a low level of pseudofeces production (PF<10\%). For all diets PF was considered as nil and, so that consumption $\approx$ ingestion.

\section{Absorption}

In most molluscs, digested food will be assimilated and/or totally or partially rejected as faeces. Under such conditions, absorption is defined as $A=1 *$ absorption efficiency (ae), defined as: ae $=100 *\left(\mathrm{OM}_{\mathrm{A}}-\mathrm{OM}_{\mathrm{F}}\right) /\left(\left(1-\mathrm{OM}_{\mathrm{F}}\right)^{*} \mathrm{OM}_{\mathrm{A}}\right)$, where $\mathrm{OM}_{\mathrm{A}}$ is the microalgae relative organic matter content and $\mathrm{OM}_{\mathrm{F}}$ is the faeces relative organic matter content (Conover, 1966).

Tanks were drained and oysters cleaned three times a week. Daily faeces production precisely established on $24 \mathrm{~h}$ was accordingly sampled on Tuesday for two types of diet and on Thursday for the other diets, with collections made using a vacuum pump onto a GF/C filter, precombusted at $450{ }^{\circ} \mathrm{C}$. Fecal samples were washed with an ammonium formate solution $\left(34 \mathrm{~g} \mathrm{~L}^{-1}\right)$ to remove adventitious salts. Total dry weight was determined after drying at $75{ }^{\circ} \mathrm{C}$ for at least $24 \mathrm{~h}$ by the difference from the filter tare while OM fraction (\%) was obtained from a second weighing after combustion in a muffle furnace at $450{ }^{\circ} \mathrm{C}$ for $4 \mathrm{~h}$. Although feeding was adjusted to limit pseudofaeces production care was taken to collect exclusively faeces during sampling so that results presented here referred to real assimilation. Thus for each diet, faeces production was achieved at least once a week during a full day, and five representative sets of data $(\mathrm{CV}<10 \%)$ were pooled to express production throughout the whole experimental period.

At the beginning and end of the experiment, the dry weight of soft body tissue of each individual (10-30 per tank) was measured to the nearest $\mathrm{mg}$ after freeze-drying at $-60^{\circ} \mathrm{C}$ for $72 \mathrm{~h}$ and the flesh dry weight increment in oysters fed the four different microalgae was used to calculate ingestion and absorption. Considering that growth was linear in that 6-week experimental period, oyster dry flesh weight at t time (Dwt) was estimated on a weekly basis as $D w_{t} \sum_{I=0}^{t}\left(\left(D w_{f}-D w_{0}\right) / 6\right)+D w_{0}$, where $D w_{0}$ is the mean outset oyster dry weight and $D w_{f}$ is the mean final oyster dry weight.

\section{Biochemical procedures}

\section{Microalgae}

For dry weight analysis, $25 \mathrm{~mL}$ samples of a microalgal suspension were filtered through precombusted $\left(450{ }^{\circ} \mathrm{C}, 24 \mathrm{~h}\right)$, preweighed, 47-mm GF/F Whatman filters. The filters were washed with $30 \mathrm{~mL}$ of $0.5 \mathrm{M}$ ammonium formate to remove residual salts, dried at $80{ }^{\circ} \mathrm{C}$ overnight and then reweighed to determine the dry weight.

For fatty acid and sterol analyses, similar harvest methods were used but filters were stored at $20^{\circ} \mathrm{C}$ in chloroform/methanol (2/1) for a period of up to 6 months before analysis based on methods similar to those used for oysters.

Oysters

At the beginning and end of broodstock conditioning period, 15 oysters per feeding condition, were dissected to sample four different organs: gonad (Gn), digestive gland (Dg), adductor muscle (Am) and gills (G). For each diet, three samples were made of each of the four organs, each sample containing the pooled tissues of five oysters; these samples were frozen in liquid nitrogen at $-196^{\circ} \mathrm{C}$ until analysis.

The different organs were then crushed using a ball grinder, and divided in two equal parts: the first one for protein and carbohydrate analysis $(\approx 200 \mathrm{mg}$ for each tissue dispensed in 2 $\mathrm{ml}$ distilled water) and the second for fatty acid and sterol analysis $(\approx 200 \mathrm{mg}$ for each tissue 
distributed in $6 \mathrm{ml}$ Folch solution (Folch et al. 1957). Aliquots of the first fraction were analyzed separately for tissue dry weight, protein (Lowry et al. 1957) and carbohydrate contents (Dubois et al. 1956). After centrifugation, the lipid extract was transferred to a clean tube, sealed under nitrogen, and stored at $-20^{\circ} \mathrm{C}$. Neutral and polar lipid extracts were separated on a Silica gel micro-column as described by Marty et al. (1992), and fatty acids in each fraction were analyzed as described in Delaporte et al. (2006) with 23:0 as an internal standard. For each tissue, fatty acid composition was expressed as weight percentage of the total fatty acids of each lipid fraction. Sterols were analyzed using the method described by Soudant et al. (2000) after transesterification with sodium methoxide (MeONa, Eder et al. 1992) in a Chrompack CP 9002 gas chromatograph equipped with a Restek Rt X 65 fused silica capillary column $(15 \mathrm{~m} \times 0.25 \mathrm{~mm}, 0.25 \mu \mathrm{m}$ film thickness) using hydrogen as carrier gas and cholestane as internal standard. Fatty acids and sterols were identified by comparison of their retention time with standards. In the present work fatty acids of the polar lipid fraction were only reported because they correspond to real assimilation. The composition of the neutral lipid fraction was also determined but mainly used to explain transfer from one organ to another or from the gonad to eggs and larvae, which was not the objective of the present work.

\section{Statistical analyses}

Statistical analyses were performed using STATISTICAsoftware (version 8.0). Significant differences were detected between the means at the 5\% threshold using ANOVA and an a postiori multiple comparison test between the means (Tuckeys' test), after transformation of percentage data by the function [arcsin (racine $\mathrm{x} i / 100)$ ].

\section{Results}

\section{Effect of food on physiological parameters}

Whatever the diet supplied, cumulative oyster mortality was low at the end of the experiment (3\%) adding confidence to the results reported here.

The mean outset oyster dry weight was $0.48 \pm 0.03 \mathrm{~g}$ while the mean final oyster dry weights ranged from $0.33 \pm 0.03 \mathrm{~g}$ ( $T$. suecica) to $0.62 \pm 0.04 \mathrm{~g}$ (S. marinoi). Similar growth dry weight increment was recorded when oyster were fed $I$. aff. galbana $(0.58 \pm 0.05 \mathrm{~g})$ or $C$. gracilis $(0.56 \pm 0.05 \mathrm{~g})$.

S. marinoï and C. gracilis induced the highest consumption $\left(7.0 * 10^{9} \pm 0.5 * 10^{9}\right.$ and $6.5 * 10^{9} \pm$ $\left.0.1 * 10^{9} \mu \mathrm{m}^{3} \mathrm{~g}^{-1} \mathrm{~h}^{-1}\right)$, with no significant differences between these diatoms, while consumption recorded with $l$. aff. galbana was approximately half $\left(3.7 * 10^{9} \pm 0.1 * 10^{9} \mu \mathrm{m}^{3} \mathrm{~g}^{-1} \mathrm{~h}^{-1}\right)$. The lowest

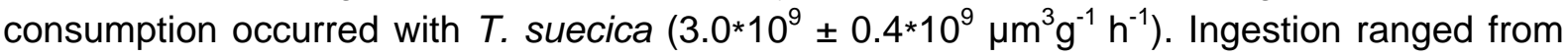
$0.36 \pm 0.05$ to $5.32 \pm 0.37 \mathrm{mg} \mathrm{g}^{-1} \mathrm{~h}^{-1}$ for $T$. suecica and $S$. marinoï respectively (Fig. 1 ). These two diatoms also led to the highest absorption $\left(2.5 \pm 0.0\right.$ and $1.9 \pm 0.2 \mathrm{mg} \mathrm{g}^{-1} \mathrm{~h}^{-1}$ for $S$. marinoï and C. gracilis respectively) and absorption efficiencies (46\% and $38 \%$ respectively) while similar low absorption and ae were recorded with T-ISO (0.32 $\pm 0.07 \mathrm{mg}$ $\mathrm{g}^{-1} \mathrm{~h}^{-1}, 19 \%$ ) and $T$. suecica (0.12 $\pm 0.0 \mathrm{mg} \mathrm{g}^{-1} \mathrm{~h}^{-1}, 33 \%$ ) (Fig. 2).

When $O$. edulis oysters were fed $I$. aff. galbana, $C$. gracilis or $S$. marinoï meat dry weight showed no significant increase over the 6 week experiment, ranging from $0.56 \pm 0.06$ to 0.62 $\pm 0.04 \mathrm{~g}$ at the end of the trial compared with $0.48 \pm 0.03 \mathrm{~g}$ at the start. In contrast those fed $T$. suecica exhibited a relative loss of weight in week $6(0.33 \pm 0.11 \mathrm{~g})$ leading to significant differences between diets on week $6(p<0.05)$. 


\section{Diet composition}

The main fatty acids and sterols found in the four microalgae used as food for $O$. edulis are reported in Table 1 . With $\approx 10 \%$ of total fatty acids T-ISO was rich in $22: 6(n-3)$ but poor in $20: 5(n-3)$ and exhibited accordingly a ratio $22: 6(n-3) / 20: 5(n-3)$ that was particularly high (x $=31$ ). With $\approx 12 \%$ (vs. $\approx 1-4 \%$ for the other species) T-ISO was also rich in 18:2(n-6) and 18:4(n-3). It was also characterized by $22: 5(n-6)$ found at1.7\%(vs. $0^{\wedge} 0.4$ for both diatoms and $T$. suecica respectively) and by brassicasterol (99\%) inexistent in the other microalgae (Table1).

With $22-23 \%$ of total fatty acids $C$. gracilis and S. marinoï were rich in 20:5(n-3) but poor in $22: 6(n-3)$ and exhibited accordingly a ratio $22: 6(n-3) / 20: 5(n-3)$ that was particularly low $(x<$ 0.2 . With $11.5-22.5 \%$ and $13.5-25.5 \%$, both diatoms contained large proportions of $16: 3(n-4)$ and 16:1(n-7) respectively (Table 1$)$. Chaetoceros gracilis was also characterized by cholesterol (51\%) and fucosterol (37\%) while S. marinoï mainly contained campesterol (37\%) and 24 mecholesterol (37\%).

With 26\% 18:1(n-9) was the prevailing monounsaturated fatty acid in $T$. suecica and with $10 \%$ 18:3(n-3) was the dominant poly-unsaturated fatty acid (Table 1$)$. It contained at least five times less 22:6(n-3) and 20:5(n-3) with, however, a similarly low ratio 22:6(n-3)/20:5(n-3) as both diatoms. In contrast, it was characterized by 16:4(n-3), inexistent in both diatoms and weakly represented in T-ISO (0.5\% vs. $\approx 6 \%)$ and by campesterol (89\%:Table 1$)$.

\section{Effect of food on biochemical composition}

The mean gonad protein ranged from 408 to $529 \mathrm{mg} \mathrm{g}^{-1}$ (Table 2). There was no protein accumulation during the conditioning process when oysters were fed any other microalga than T-ISO $(p<0.05)$. With the diatoms $(C$. gracilis and S. marinoi $)$, a protein decrease was observed in $O$. edulis digestive gland and adductor muscle, while $T$. suecica did not induce any significant change in any organ apart from a decrease in muscle $(p<0.05)$. Mean gonad carbohydrates ranged from 79 to $141 \mathrm{mg} \mathrm{g}^{-1}$ (Table 2). Gonads accumulated carbohydrates when $O$. edulis were fed any microalgae except T-ISO $(p<0.05)$ and the extent of accumulation depended on algal species supplied: $T$. suecica $<C$. gracilis $<S$. marinoï $(p<$ 0.05). In contrast, carbohydrates accumulated in the digestive gland irrespective of diet, while no significant transfer occurred to the muscle or gills (Table 2).

The main fatty acids found over all organs and diets were 16:0, 20:5(n-3) and 22:6(n-3), with values varying from 4.5 to $20.7 \%$ (gonad: Table 3; digestive gland: Table 4; adductor muscle: Table 5; gills: Table 6). When fed either diatom oysters showed a significant enrichment in EPA (20:5(n-3)) in the polar lipids of the gonad though in presence of $T$. suecica or T-ISO, EPA was either maintained or catabolized (Table 3). The three other organs showed similar ecosapentaenoic acid content evolution in polar lipids (Tables 4 to 6). On the other hand, when oysters were fed T-ISO there was a significant and exclusive enrichment in gonad docosahexaenoic acid (DHA, 22:6(n-3)) in the neutral fraction (data not showed here) but not in the polar faction (Table 3). No DHA variation occurred in the other organs (Tables 4 to 6). When either diatom was supplied, DHA was catabolized in all organs but with $T$. suecica it remained constant (Tables 3 to 6). When oysters were fed T-ISO, enrichment in 22:5(n-6), a fatty acid characteristic of this Haptophyceae, was recorded in all tissues (Tables 3 to 6 ). However, when oysters when fed $T$. suecica no 16:4(n-3) evolution was noted in any of the organs (Tables 3-6), even though this fatty acid is characteristic of this Prasinophyceae (Table 1).

No noticeable evolution occurred for the other main fatty acids including arachidonic acid, 20:4(n-6) which represented approximately 3 to $4 \%$ of total fatty acids in all treatments (Tables 3 to 6 ).

When oysters were fed T-ISO, brassicasterol enrichment was measured in all organs, while oysters fed both diatoms showed depletion in this sterol for gonad, digestive gland and gills 
(Table 7). On the other hand when flat oysters were fed C. gracilis, specific cholesterol enrichment occurred in all organs except muscle. Similar trends were found for campesterol contents in oysters fed S. marinoï (Table 7). In contrast, when oysters were fed T. suecica, no differences in sterol composition were observed (Table 7) despite campesterol's dominant position in that microalgae (Table1).

\section{Fecundity}

When flat oysters were fed T-ISO, a total of 1.4 million larvae were harvested during the experimental period (6 weeks). After feeding with $C$. gracilis or S. marinoï, 1 million larvae were released, but only 0.3 million larvae were produced when the breeders were given $T$. suecica. Fecundity was therefore $0.04,0.03$ and $0.005 * 10^{6}$ larvae per female in T-ISO, diatoms and $T$. suecica, respectively (supposing an initial sex ratio of 1:1). At release larvae varied in length from 165 to $179 \mu \mathrm{m}$, showing no significant differences $(p<0.05)$ in size.

\section{Discussion}

Bivalve physiological parameters like consumption or ingestion in bivalves depends on the reproductive cycle (Gabbott \& Bayne 1973), type and food availability (Thompson \& Bayne 1974; Defossez \& Hawkins 1997; Albentosa et al. 2007) and temperature (Ansell 1973; Newell \& Branch 1980). The present study reports the influence of food supply (different species of microalgae) on food acquisition parameters in O. edulis (L.) over a 6 week period under controlled conditions. A biochemical study was simultaneously carried out on four tissues at the beginning and end of the experimental period measuring the food imprinting to follow the assimilation. These complementary approaches will be discussed.

\section{Impact of diet on physiological responses}

Ingestion in $O$. edulis was clearly related to diet. The high values reported for $C$. gracilis and S. marinoï $\left(\approx 5 \mathrm{mg} \mathrm{g}^{-1} \mathrm{~h}^{-1}\right)$ contrast with those of T-ISO and T. suecica $\left(<1.7 \mathrm{mg} \mathrm{g}^{-1} \mathrm{~h}^{-1}\right)$. Indeed it is known that filter mollusks regulate their ingestion by physical mechanism (Bayne et al. 1987; Navarro et al. 1994; Bacon et al. 1998). Diatoms showed better absorption compared with both T-ISO and T. suecica. When oysters were fed T-ISO their absorption was 6 to 8 fold less than with diatoms. This value represents $50 \%$ of that reported in $C$. gigas (Ropert \& Goulletquer 2000) fed however a bi-specific diet of T-ISO and T. suecica $\left(0.72 \mathrm{mg} \mathrm{g}^{-1} \mathrm{~h}^{-1}\right)$. Such data also contrasts also with the values reported in Glycymeris glycymeris and Phaphia romboïdes where $80-90 \%$ ae was obtained with a plurispecific diet supply (Savina \& Pouvreau 2004). Despite moderate T-ISO ingestion and absorption efficiency no differences in $O$. edulis growth (expressed in meat dry weight) were observed compared with oysters receiving diatom diets. Although, absorption efficiency recorded in oysters fed $T$. suecica was close to the values obtained with diatoms (40\% vs $33 \%$ ), the absorption value was 15 to 20 fold due to lowered ingestion level.

\section{Impact of diet on biochemical composition of oyster tissues}

In the present work, gonads accumulated carbohydrates when $O$. edulis were fed three microalgae except T-ISO and values can be ranked as follows: $T$. suecica $<C$. gracilis $<S$. marinoï. Carbohydrate storage and its utilization result in a balance between food supply and energetic demand for reproduction and growth. Carbohydrate exhaustion is consequently read as a catabolism of reserves for gametogenesis processes. Thus, carbohydrates 
depletion is reported during conditioning, in C. gigas (Moal et al. 1991; Berthelin et al. 2000; Delaporte et al. 2006).

Because oysters fed T-ISO exhibited lower carbohydrate and higher protein contents than the other diets in week 6, gametogenesis can be supposed to be more advanced or delayed. Former hypothesis is being tested with a histological study of gametogenesis in relation to diet (analysis in progress) but can already be proposed because the first $O$. edulis larval release occurred after feeding with this haptophyceae (0.6 million in week 4$)$. For marine bivalves, reproductive cycle is initially linked to glycogen storage cycle (Berthelin et al. 2000). After an initial period of storage, stocked glycogen is used concomitantly with food as an energetic support of gametogenesis. A similar relation between carbohydrate and protein has been already reported (Gabbot \& Walker 1971) in the natural environment but the opposite pattern was described when broodstock was fed a mixed diet of Tetraselmis suecica + Isochrysis galbana under controlled conditions. Such contrasting results within the same study (natural/hatchery: Gabbot \& Walker 1971) and between the experiments of this previous study and our own) could be explained by the low feeding concentration used in this previous study ( 2 cells $\mu^{-1}$ ) which led to a decrease in $O$. edulis condition index in the controlled environment. Under these conditions it is not surprising that our results are not in agreement, because, in the present work, flat oysters were fed ad libitum (1 billion cells TISO equivalent per day) representing 20 to 24 cells $\mu^{-1}$, which is 10 fold higher than the level used by Gabbot \& Walker (1971). In this previous study the initial reserves would certainly have played a preponderant role in the allocation of biochemical components between the tissues. Lastly, the data in this previous study were based on whole body flesh whereas our results report the composition of specific tissues separately.

Using a similar study technique (specific organ biochemical allocation) Delaporte et al. (2006) reported a similar trend in C. gigas, where protein and glycogen contents were inversely correlated during conditioning, with maximal protein value recorded during spawning.

Generally lipids are issued from carbohydrate catabolism (lipogenesis). However, most of the lipids that accumulated in gonads during gametogenesis are directly obtained from diet or by transfer from other tissues. This is particularly true for PUFA and sterols, which are weakly biosynthesized by bivalves (Chu \& Greaves 1991) and cannot thus be obtained from carbohydrate lipogenesis or neosynthesized. So tissue specific fatty acid and sterol variations are well related to food composition with a possible and variable metabolism buffering (Palacios et al. 2005, Soudant et al. 1996).

The initial fatty acid composition of polar lipids is similar in all analysed tissues with a preponderance of PUFA ( $\approx 50 \%)$. Fatty acids of the $n-3$ family are always greater than those of n-6 family leading to a n-3/n-6 ratio $>1$. These results are in accordance with data reported on natural O. edulis population in Spain (Abad et al. 1995). In the present work, EPA and DHA, were the major fatty acids detected in all organs (gonad, digestive gland, muscle and gills). These results agree with fatty acids seasonal variations in $O$. edulis (Abad et al. 1995), Chlamys tehuelcha (Pollero, 1979) and Crassostrea virginica (Trider \& Castell, 1980). When oysters were fed the diatoms Chaetoceros gracilis and Skeletonema marinoï, there was a specific accumulation of 20:5(n-3) or 22:6(n-3) when they were fed T-ISO. These results are partially in agreement with those of Frolov \& Pankov (1992) who reported a high correlation (0.65) between the supply of these two particular fatty acids and their concentration in $O$. edulis gonads. Whatever the diet delivered and its microalgal fatty acid composition $O$. edulis gonads accumulated roughly the same amount of $20: 5(n-3)$, varying from 8.5 to $10.7 \%$ (Frolov \& Pankov 1992). Our study does not fully agree with this result because EPA varied from 5.5 to $17.3 \%$ and a relation was shown between microalgae EPA content and gonad enrichment, with the highest values corresponding to diatoms and the lowest to T-ISO. Moreover 22:6(n-3) varied from 6.5 to $11.2 \%$ in the study by Frolov \& Pankov (1992), with only a cumulative effect when a mixed diet was fed while in the present work DHA exhibited a similar low-end value (7\%) but higher content, $15 \%$, after feeding with T-ISO, a microalga known to be particularly rich in this fatty acid. In $O$. edulis gonads a specific enrichment in EPA and DHA occurred (Frolov \& Pankov 1992) that seemed to 
indicate the specific role of these fatty acids in reproduction. This pattern must however be partially incorrect because the present work shows that such enrichment also occurs in the other organs for the neutral fraction (data not reported) with the exception of the gills for DHA. This means that there is no specific allocation of these two fatty acids to $O$. edulis gonads.

Excepted the muscle all tissues showed the same variations than those observed in the gonad. The good and similar relation between the FA supply in the food and its incorporation in the different oyster tissues emphasized the importance of the food and the active transfer from the digestive gland to other tissues during gametogenesis. The absence of a specific imprinting of the gonad compared to other tissues may signify a precocious stage of gametogenesis, with a gonad little developed. In contrast, the specific composition of muscle, more independent of the food composition, means a strict FA regulation of this tissue, and a specific need for DHA to maintain its function.

Sterols, on the other hand, are known to play an important role in living organisms as structural components of cell membranes, steroid hormones and vitamin D precursors (Soudant et al. 2000). After 6 weeks of experimentation the relative sterol composition of the organs was significantly influenced by diet composition. In oysters fed different mono-specific diets, the main sterols, characteristic of each microalgae species were allocated to all tissues except muscle. Thus, for oysters fed $C$. gracilis, cholesterol, which represented $60 \%$ of total sterols, was efficiently transferred to the gonads (from $32 \%$ on week 0 to $47 \%$ on week 6) and other organs. Similar enrichment was recorded for campesterol in oysters fed S. marinoï (35\% of total sterols). Diatoms have been shown to be well assimilated by $O$. edulis and biochemical studies confirmed that their main representative fatty acids (EPA) and sterols (cholesterol and campesterol) are efficiently transferred to the flat oyster gonad as well as to most of the other tissues.

In the present work $T$. suecica is poorly absorbed when using a physiological study. This result was confirmed by biochemical analysis where no significant enrichment in the main fatty acids was found, in any tissue, at the end of the 6-week feeding experiment. Thus, 16:4(n-3), which is characteristic of this Prasinophyceae (Volkman et al. 1989; Robert et al. 2004), did not show any variation in the gonad in the present work. Moreover, campesterol represents $80 \%$ of sterols in this species, but oysters fed $T$. suecica did not show any differences in allocation of this specific sterol. Because such trends also occurred in the other organs, $T$. suecica did not offer any benefit for $O$. edulis broodstock conditioning or maintenance in controlled conditions. The low food value of this alga for flat oyster was also indicated by a relative decrease in mean dry weight and weak fecundity in oysters fed this diet: larval release probably arose from the utilization of original reserves.

From an ecophysiological point of view T-ISO ranked in an intermediate position. This result was confirmed with an additional trial (data not shown) using a refreshed strain of T-ISO (also obtained from the CCAP). Indeed, as absorption efficiency was only $20 \%$ doubts can be raised about its effective value for broodstock conditioning. Biochemical analysis and specifically 22:5(n-6), characteristic of this Haptophyceae (Volkman et al. 1989; Robert et al. 2004) clearly showed that this microalgae is efficiently incorporated into the gonad and the other tissues, including gills. Moreover, brassicasterol, which represented $90 \%$ of the total sterols in T-ISO, was efficiently transferred and accumulated in all O. edulis organs (from 17 $\%$ in week 0 to $45 \%$ in week 6 ). Moreover the highest fecundity was recorded when $O$. edulis was fed T-ISO although such results should be analysed carefully because the whole flat oyster spawning season can last up to 3 months (Helm et al. 1973, González-Araya et al, unpublished data) and a previous study under controlled conditions reported that early larval release and total fecundity were not related (González-Araya et al, unpublished data). These two approaches therefore gave conflicting results on the role of T-ISO in O. edulis conditioning. Such contradictory results have already been reported with this same microalgae when considering C. gigas larval development. Indeed, when fed as monospecific diet, this microalgae is poorly ingested and larval development is accordingly rather low. In contrast, when the diatom Chaetoceros calcitrans forma pumilum, is mixed with T-ISO in different proportions, microalgae uptake increases significantly, resulting in the better 
larval performance (Rico-Villa et al. 2006) that is higher and more reproducible than that obtained with the diatom alone. Such additive effects have often been attributed to a better balance in dietary components (Helm et al. 2004), which is true when considering EPA and DHA but which should also be explained by a higher food uptake. Because T-ISO is not efficiently assimilated by $O$. edulis, it should be rejected from an ecophysiological point of view. However its high DHA content $(15 \%)$ and its efficient transfer from microalgae to flat oyster tissues, including the gonad, makes it difficult to replace. Another microalga, rich in DHA exhibiting higher absorption efficiency, needs to be found to efficiently replace T-ISO. Rhodomonas salina is one potential species whose performances we will examine in a forthcoming paper, part B of this work

\section{Conclusion}

C. gracilis and S. costatum are both efficient for $O$. edulis conditioning because of their physiological responses and efficient transfer of EPA and characteristic sterols.

In contrast $T$. suecica holds no interest $O$. edulis conditioning due to its low ingestion and absorption as well as the poor transfer of dietary components.

Conflicting results were found for T-ISO showing weak physiological responses contrasting with efficient transfer and allocation of DHA and brassicasterol.

A mixed diet is therefore recommended for $O$. edulis conditioning to offer a dietary balance. C. gracilis (or S. marinoi) + T-ISO is proposed but a substitute for T-ISO should also be sought.

\section{Acknowledgments}

This work could not have been completed without the technical support of the team at the Argenton Ifremer station - C. Mingant, L. Lebrun and P. Le Souchu - plus the help of a project student L. David, all of whom we wish to thank. We are also grateful to the Universidad de Los Lagos (MECESUP-ULA 03/02) which contributed to the funding of a PhD grant for the first author. This work was carried out during the SETTLE project and was partially funded by FP7/2007-2013 under agreement $n^{\circ} 222043$.

\section{References}

Abad M., Ruiz C., Martinez D., Mosquera G. \& Sanchez J.L. (1995). Seasonal variation of lipids classes and fatty acids in flat oysters, Ostrea edulis from San Cibran (Galicia, Spain). Comp. Biochem. Physiol., (110 C), 109-118.

Albentosa M., Fernández-Reiriz M.J., Labarta. \& Pérez-Camacho A. (2007). Response of two species of clams, Ruditapes decussatus and Venerupis pullastra, to starvation: Physiological and biochemical parameters. Comparative Biochemistry and Physiology, Part B 146, 241-249.

Ansell A.D. (1973). Oxygen consumption by the bivalve Donax vittatus (da Costa). J. Exp. Mar. Biol. Ecol. 11, 311-328.

Bacon G.S., MacDonald B.A.\& Ward J.E. (1998). Physiological responses of infaunal (Mya arenaria) and epifaunal (Placopecten magellanicus) bivalves to variation in the concentration and quality of suspended particles. I. Feeding activity and selection. J. Exp. Mar. Biol. Ecol. 219, 105-125.

Bayne B.L., Hawkins A.J.S. \& Navarro E. (1987). Feeding and digestion by the mussel Mytilus edulis in mixtures of silt and algal cells at low concentrations. J. Exp. Mar. Biol. Ecol. 11, 1-22. 
Beiras R., Camacho A.P.\& Albentosa M. (1994). Comparison of the scope for growth with the growth performance of Ostrea edulis seed reared at different food concentrations in an open system. Mar. Biol. 119(2), 227-233.

Berntsson K.M., Jonsson P.R., Wängberg S.Å. \& Carlsson A.S. (1997). Effects of broodstock diets on fatty acid composition, survival and growth rates in larvae of the European flat oyster, Ostrea edulis. Aquaculture 154, 139-153.

Berthelin C., Kellner K. \& Mathieu M., 2000. Storage metabolism in the Pacific oyster (Crassostrea gigas) in relation to summer mortalities and reproductive cycle (West Coast of France). Comp. Biochem. Physiol. 125 B, 359-369.

Brown M.R., Jeffrey J.K., Volkman J.K. \& Dunstan G.A. (1977). Nutritional properties of microalgae for mariculture. Aquaculture 151, 315-331.

Carnegie R.B. \& Cochennec-Laureau N. (2004). Microcell parasites of oysters: recent insights and future trends. Aquat. Living Resour. 17, 519-528.

Comps M. (1970). Observation sur les causes d'une mortalité anormale des huîtres plates dans le basin de Marennes. Rev. Trav. Inst. Pêches marit. 34 (3), 317-326.

Comps M., Tige G. \& Grizel H. (1980). Recherches ultrastructurales sur un protiste parasite de l'huître plate Ostrea edulis L. C. R. Acad. Sci. Paris, 290 D, 383-384.

Conover R.J. (1966). Assimilation of organic matter zooplankton. Limnol. Oceanogr. 11 (3), 338-345.

Coutteau P. \& Sorgeloos P. (1992). The use of algal substitutes and the requirement for live algae in the hatchery and nursery rearing of bivalve molluscs: an international survey. $J$. Shellfish Res. 11 (2), 467-476.

Culloty S.C. \& Mulcahy M.F. (1996). Season-, age-, and sex-related variation in the prevalence of bonamiasis in flat oysters (Ostrea edulis L.) on the south coast of Ireland. Aquaculture 144, 53-63.

Defossez J.M. \& Hawkins A.J.S. (1997). Selective feeding in shellfish: size-dependent rejection of large particles within pseudofaeces from Mytilus edulis, Ruditapes philippinarum and Tapes decussatus. Mar. Biol. 129, 139-147.

Delaporte M., Soudant P., Lambert C., Moal J., Pouvreau S. \& Samain J.-F. (2006). Impact of food availability on energy storage and defence related haemocyte parameters of the Pacific oyster Crassostrea gigas during an experimental reproductive cycle. Aquaculture 254, 571-582.

Dubois M., Gilles K.A., Hamilton J.K., Rebers P.A. \& Smith F. (1956). Colorimetric method for determination of sugars and related substances. Anal. Chem. 28, 350-356

Folch J.M., Lee M. \& Sloane-Stanley G.H. (1957). A simple method for the isolation and purification of total lipids from animal tissues. J. Biol. Chem. 266, 497-509.

Frolov A.V. \& Pankov S.L. (1992). The reproduction strategy of oyster Ostrea edulis L. from the biochemical point of view. Comp. Biochem. Physiol. 103B, 161-182.

Gabbot P.A. \& Bayne B.L. (1973). Biochemical effects of temperature and nutritive stress on Mytilus edulis L. J. Mar. Biol; Assoc. UK. 53, 269-286.

Gabbott P.A. \& Walker A.J.M. (1971). Changes in the condition index and biochemical content of adult oysters (Ostrea edulis L.) Maintained under hatchery conditions. J. Cons. int. Explor. Mer. 34, 99-106.

Helm M.M. \& Millican P.F. (1977). Experiments in the hatchery of Pacific oyster larvae (Crassostrea gigas Thunberg). Aquaculture 11, 1-12.

Helm M.M. \& Pellizzato M. (1990). Riproduzione ed allevamento in schiuditoio della specie Tapes philippinarum. p 117-140. In G. Allessandra (ed) Tapes philippinarum: Biologia e Sperimentazione. Ente Svillupo Agricolo Veneto, Venice, Italy: 299 pp.

Helm M.M., Holland D.L. \& Stephenson R.R. (1973). The effect of supplementary algal feeding of a hatchery breeding stock of Ostrea edulis L. on larval vigour. J. mar. biol. Ass. U.K. 53, 673-684.

Helm M.M., Bourne N. \& Lovatelli A. (2004). Hatchery culture of bivalves. A practical manual. FAO Fisheries Technical Paper. N471, Rome FAO, 177p.

Hendriks I.E., van Duren L.A. \& Herman P.M.J. (2003). Effect of dietary polyunsaturated fatty acids on reproductive output and larval growth of bivalves. J. Exp. Biol. Ecol. 296, 199-213. 
Knauer J. \& Southgate P.C. (1999). A review of the nutritional requirements of bivalves and the development of alternative and artificial diets for bivalve aquaculture. Rev. Fish. Sci. 7, 241-280.

Laing I., Walker P. \& Areal F. (2005). A feasibility study of native oyster (Ostrea edulis) stock regeneration in the United Kingdom. CARD Project FC1016, Native oyster Stock Regeneration - A review of Biological, Technical and Economic Feasibility, 95 pp.

Lowry O.H., Rosebrough N.J., Farr A.L. \& Randall R.J. (1957). Protein measurement with the Folin phenol reagent. J. Biol. Chem. 193, 65-275.

Marty Y., Delaunay F., Moal J. \& Samain J;-F. (1992). Changes in the fatty acid composition of Pecten maximus (L.) during larval development. J. Exp. Mar. Biol. Ecol. 163, 221-234.

Ropert M. \& Goulletquer P. (2000). Comparative physiological energetics of twosuspension feeders: polychaete annelid Lanice Conchilega (Pallas 1766) and Pacific cupped oyster Crassostrea gigas (Thunberg 1795). Aquaculture 181, 171-189

Millican P.F. \& Helm M.M. (1994). Effects of nutrition on larvae production in the European flat oyster, Ostrea edulis. Aquaculture 123, 83-94.

Moal J., Le Coz J.R., Samain J.F., Daniel J.Y. \& Bodoy A. (1991). Oyster adenylate energy charge: response to levels of food. Aquat. Living Resour. 4, 133-138

Montes J., Villalba A., López M.C., Carballal, M.J. \& Mourelle S.G. (1991). Bonamiasis in native flat oysters (Ostrea edulis L.) from two intertidal beds of the Ortigueira Estuary (Galicia, N.W. Spain) with different histories of oyster culture. Aquaculture 93, 213-224.

Navarro E., Iglesias J.I.P., Ortega M. \& Larrexea X. (1994). The basis for a functional response to variable food quantity and quality in cockles Cerastoderma edule (Bivalvia, Cardiidae). Physiol. Zool. 67, 468-496.

Newell R.C. \& Branch G.M. (1980). The influence of temperature on the maintenance of metabolic energy balance in marine invertebrates. Adv. Mar. Biol. 17, 329-396.

Palacios E., Racotta I.S., Kraffe E., Marty Y., Moal J. \& Samain J.F. (2005). Lipid composition of the giant lion's-paw scallop (Nodipecten subnodosus) in relation to gametogenesis: I. Fatty acids. Aquaculture 250, 270-282.

Pernet F., Tremblay R. \& Bourget E. (2003). Biochemical indicator of sea scallop (Placopecten magellanicus) quality based on lipid class composition. Part II: Larval growth, competency and settlement. J. Shellfish Res. 22 (2), 377-388.

Rico-Villa B., Le Coz J.R., Mingant C. \& Robert R. (2006). Influence of phytoplankton diet mixtures on microalgae consumption, larval development and settlement of the Pacific oyster Crassostrea gigas (Thunberg). Aquaculture 256, 377-388.

Robert R. \& Gérard A. (1999). Bivalve hatchery technology: the current situation for the Pacific oyster, Crassostrea gigas, and the scallop Pecten maximus in France. Aquat. Living Resour. 12 (2), 121-130.

Robert R. \& Trintignac P. (1996). Microalgues et nutrition larvaire en écloserie de mollusques. Haliotis 26, 1-13.

Robert R. \& Trintignac P. (1997). Substitutes for live microalgae in mariculture. Aquat. Living Resour. 10 (6), 315-327.

Robert R., Chrétiennot-Dinet M.J., Kaas R., Martin-Jézéquel V., Moal J., Le Coz J.R., Nicolas J.L., Bernard E., Connan J.P., Le Dean L., Gourrierec G. Leroy B. \& Quéré C. (2004). Amélioration des productions phytoplanctoniques en écloserie de mollusques: caractérisation des microalgues fourrage, RI DRV/RA-2004-05, $149 \mathrm{p}$

Samain J.F. \& Mc Combie H. (2008) Summer mortality of Pacific oyster Crassostrea gigas. The Morest project, Edition Quae,Versailles, France,400 pp.

Savina M. \& Pouvreau S. (2004). A comparative ecophysiological study of two infaunal filterfeeding bivalves: Paphia rhomboïdes and Glycymeris glycymeris. Aquaculture 239, 289-306. Soudant P., Marty Y., Moal J., Robert R., Quéré C., Lecoz J.R. \& Samain J.-F. (1996). Effect of food fatty acid and sterol quality on Pecten maximus gonad composition and reproduction process. Aquaculture 143, 361-378.

Soudant P., Val Sanles M., Quéré C., Le Coz J.R., Marty Y., Moal J., Samain J.F. \& Sorgeloos P. (2000). The use of lipid emulsions for sterol supplementation of spat of the Pacific oyster, Crassostrea gigas. Aquaculture 184, 315-326. 
Thompson J. \& Bayne B.L. (1974). Some relationships between growth, metabolism and food in the mussel Mytilus edulis. Mar. Biol. 27, 317-326.

Torkildsen L. \& Magnesen T. (2004). Hatchery production of scallop larvae (Pecten maximus) - survival in different rearing systems. Aquaculture International 12 (4-5), 489-507.

Trider D.J. \& Castell J.D. (1980). Effects of dietary lipids on growth tissue composition and metabolism of the oyster (Crassostrea virginica). J. Nut. 110, 1303-1309.

Utting S.D. \& Spencer B.E. (1991). The hatchery culture of bivalve mollusc larvae and juveniles. Leaflet Laboratory of Ministry of Agriculture, Fisheries and Food, Directorate of Fisheries Research, Lowestoft, 68. 31 pp.

Utting S.D. \& Millican P.F. (1997). Techniques for the hatchery conditioning of bivalve broodstocks and the subsequent effect on egg quality and larval viability. Aquaculture 155, 45-54.

van Banning P. (1990). The life cycle of the oyster pathogen Bonamia ostreae with a presumptive phase in the ovarian tissue of the European flat oyster, Ostrea edulis. Aquaculture 84, 189-192.

Volkman J. K., Jeffrey S. W., Nichols P. D., Rogers G. I. \& Garland C. D. (1989). Fatty acid and lipid composition of 10 species of microalgae used in mariculture. J. Exp. Mar. Biol. Ecol., 128 : 219-240.

Volkman J.K. \& Brown M.R. (2006). Nutritional value of microalgae and applications. In: Subba Rao, D.V. (Ed.), Algal Cultures, Analogues of Bloom and Applications. Science Publishers, Enfield (NH), USA, pp. 407-457.

Walne P.R. (1966). Large scale culture of larvae of Ostrea edulis L. Fishery Investigations, Series II, Volume XXV, Number 4, 52 pp.

Walne P.R. (1970). Studies on the food value of nineteen genera of algae to juvenile bivalves of the genera Ostrea, Crassostrea, Mercenaria and Mytilus. Fishery Investigations, Series II, Volume XXVI, Number 5, 61 pp.

Walne P.R. (1974). Culture of bivalve molluscs, 50 years experience at Conwy, Fishing News Book, 1974, 189 pp. 
Table 1 Fatty acid and sterol composition of the total lipids of Isochrysis affinis galbana, Chaetoceros gracilis, Skeletonema marinoï and Tetraselmis suecica expressed as the mean relative content ( $w t \%$ of total acids $\pm S D, n=3$ ).

Table 2 Protein and carbohydrate mean absolute contents $\left(\mathrm{mg} \mathrm{dwg}^{-1} \pm \mathrm{SD}, \mathrm{n}=3\right)$ in the gonad, digestive gland, muscle and gills of European flat oyster Ostrea edulis broodstock fed four microalgae species.

Table 3. Total polar fatty acid composition of the polar fraction in gonad of oysters fed mono-specific diets expressed in mean absolute $\left(\mu \mathrm{g} \mathrm{mg}^{-1} \pm \mathrm{SD}, \mathrm{n}=3\right)$ and relative contents (wt \% of total polar acids \pm SD, $n=3$ ).

Table 4. Total polar fatty acid composition of the polar fraction in digestive gland of oysters fed mono-specific diets expressed in mean absolute $\left(\mu \mathrm{g} \mathrm{mg}{ }^{-1} \pm \mathrm{SD}, \mathrm{n}=3\right)$ and relative contents (wt \% of total polar acids $\pm S D, n=3$ ).

Table 5. Total polar fatty acid composition of the polar fraction in muscle of oysters fed mono-specific diets expressed in mean absolute $\left(\mu \mathrm{g} \mathrm{mg}{ }^{-1} \pm \mathrm{SD}, \mathrm{n}=3\right)$ and relative contents (wt \% of total polar acids $\pm S D, n=3$ ).

Table 6. Total polar fatty acid composition of the polar fraction in gills of oysters fed mono-specific diets expressed in mean absolute $\left(\mu \mathrm{g} \mathrm{mg}^{-1} \pm \mathrm{SD}, \mathrm{n}=3\right)$ and relative contents (wt \% of total polar acids $\pm S D, n=3$ ).

Table 7 Sterol composition of of different tissues of Ostrea edulis fed mono-specific diets (weight \%, \pm S.D.) 
Table 1

\begin{tabular}{|c|c|c|c|c|c|c|c|c|}
\hline \multirow{2}{*}{ Fatty acid } & \multicolumn{8}{|c|}{ Oyster diets } \\
\hline & \multicolumn{2}{|c|}{ I. aff. galbana } & \multicolumn{2}{|c|}{ C. gracilis } & \multicolumn{2}{|c|}{ S. marinoï } & \multicolumn{2}{|c|}{ T. suecica } \\
\hline $14: 0$ & 18.97 & (8.83) & 10.12 & (1.13) & 9.64 & $(0.46)$ & 1.22 & $(0.77)$ \\
\hline $16: 0$ & 9.37 & (0.19) & 11.09 & $(0.71)$ & 6.66 & $(0.53)$ & 30.82 & (1.23) \\
\hline $18: 0$ & 0.22 & $(0.47)$ & 0.00 & $(0.00)$ & 0.00 & $(0.00)$ & 1.03 & $(0.15)$ \\
\hline $20: 0$ & 0.10 & $(0.01)$ & 0.01 & (0.01) & 0.00 & $(0.00)$ & 0.00 & $(0.00)$ \\
\hline $22: 0$ & 0.00 & $(0.00)$ & 0.23 & $(0.01)$ & 0.08 & $(0.08)$ & 0.11 & (0.11) \\
\hline $24: 0$ & 0.11 & $(0.05)$ & 0.00 & $(0.00)$ & 0.00 & $(0.00)$ & 0.02 & $(0.04)$ \\
\hline $16: 1(n-9)$ & 0.63 & $(0.15)$ & 0.00 & $(0.00)$ & 0.00 & $(0.00)$ & 2.79 & $(0.29)$ \\
\hline $16: 1(n-7)$ & 5.05 & $(0.39)$ & 25.37 & $(0.57)$ & 13.44 & (1.63) & 0.39 & $(0.25)$ \\
\hline $18: 1(n-9)$ & 12.09 & $(0.51)$ & 0.77 & $(0.18)$ & 0.00 & $(0.00)$ & 26.39 & (4.51) \\
\hline $18: 1(n-7)$ & 1.15 & $(0.10)$ & 0.48 & $(0.08)$ & 0.22 & $(0.06)$ & 2.83 & $(0.90)$ \\
\hline $16: 2(n-7)$ & 0.22 & $(0.01)$ & 2.64 & $(1.76)$ & 5.76 & $(0.05)$ & 0.00 & $(0.00)$ \\
\hline $16: 2(n-6)$ & 0.00 & $(0.00)$ & 0.00 & $(0.00)$ & 0.00 & $(0.00)$ & 0.55 & $(0.10)$ \\
\hline $16: 2(n-4)$ & 0.51 & $(0.12)$ & 3.34 & $(0.38)$ & 2.34 & $(0.04)$ & 0.01 & $(0.01)$ \\
\hline $16: 3(n-4)$ & 0.29 & $(0.24)$ & 11.61 & (2.22) & 22.55 & (3.13) & 0.00 & $(0.00)$ \\
\hline $16: 4(n-3)$ & 0.52 & $(0.01)$ & 0.00 & (0.00) & 0.00 & $(0.00)$ & 5.81 & (3.91) \\
\hline $16: 4(n-1)$ & 0.00 & $(0.00)$ & 0.00 & (0.00) & 1.78 & (0.09) & 0.00 & $(0.00)$ \\
\hline $18: 2(n-6)$ & 11.62 & (3.47) & 1.17 & $(0.43)$ & 1.24 & (0.05) & 3.55 & $(0.46)$ \\
\hline $18: 2(n-4)$ & 0.01 & $(0.04)$ & 0.05 & $(0.05)$ & 0.12 & $(0.00)$ & 0.00 & $(0.00)$ \\
\hline $18: 3(n-6)$ & 1.34 & $(0.26)$ & 1.07 & $(0.04)$ & 0.41 & (0.13) & 0.41 & $(0.14)$ \\
\hline $18: 3(n-3)$ & 6.12 & (0.59) & 0.21 & $(0.05)$ & 0.55 & (0.01) & 9.69 & (1.32) \\
\hline $18: 4(n-3)$ & 12.07 & (3.19) & 0.94 & $(0.06)$ & 4.03 & $(0.72)$ & 4.15 & (1.02) \\
\hline $18: 5(n-3)$ & 2.15 & $(0.10)$ & 0.00 & $(0.00)$ & 0.00 & $(0.00)$ & 0.09 & (0.07) \\
\hline $20: 4(n-6)$ & 0.23 & $(0.19)$ & 1.39 & (0.09) & 0.43 & (0.04) & 0.51 & (0.08) \\
\hline $20: 5(n-3)$ & 0.33 & (0.18) & 22.66 & (0.14) & 21.88 & (1.11) & 4.44 & $(0.62)$ \\
\hline $22: 5(n-6)$ & 1.70 & (1.03) & 0.00 & (0.00) & 0.03 & (0.00) & 0.42 & $(0.29)$ \\
\hline $22: 5(n-3)$ & 0.09 & $(0.05)$ & 0.03 & (0.01) & 0.03 & $(0.00)$ & 0.01 & (0.01) \\
\hline $22: 6(n-3)$ & 10.17 & $(2.54)$ & 1.11 & $(0.51)$ & 4.40 & $(0.21)$ & 0.23 & $(0.08)$ \\
\hline TO. SAT. & 29.48 & $(9.40)$ & 22.04 & $(0.50)$ & 16.82 & $(1.08)$ & 33.29 & (1.31) \\
\hline TO. MONO & 20.45 & $(1.24)$ & 28.18 & $(0.16)$ & 15.48 & $(0.53)$ & 34.19 & $(4.87)$ \\
\hline TO.(n-9) & 12.89 & $(0.34)$ & 0.93 & $(0.34)$ & 0.34 & $(0.00)$ & 30.44 & (4.71) \\
\hline TO.(n-7) & 7.28 & (1.13) & 26.44 & $(0.47)$ & 14.24 & $(0.57)$ & 3.31 & $(0.95)$ \\
\hline TO. POLY & 48.37 & $(8.04)$ & 47.08 & $(1.40)$ & 65.73 & $(1.61)$ & 32.14 & (5.05) \\
\hline TO.(n-4) & 0.81 & $(0.40)$ & 15.00 & (1.79) & 25.01 & $(0.06)$ & 0.01 & $(0.01)$ \\
\hline TO.(n-6) & 15.15 & (7.23) & 4.01 & (0.63) & 2.16 & $(0.26)$ & 6.23 & $(0.75)$ \\
\hline TO.(n-3) & 32.07 & $(0.70)$ & 25.33 & $(0.66)$ & 30.96 & $(1.46)$ & 25.52 & (5.12) \\
\hline$(n-3) /(n-6)$ & 2.12 & $(1.86)$ & 6.32 & $(1.37)$ & 14.35 & $(0.04)$ & 4.14 & $(0.91)$ \\
\hline $22: 6 / 20: 5$ & 31.07 & (6.67) & 0.05 & $(0.02)$ & 0.20 & $(0.01)$ & 0.05 & $(0.01)$ \\
\hline fg cell ${ }^{-1}$ & 1367.60 & 518.79 & 1848.86 & 87.29 & 1776.82 & 523.20 & 11565.40 & 3134.07) \\
\hline \multicolumn{9}{|l|}{ Sterols } \\
\hline Cholesterol & 0.67 & $(0.09)$ & 50.94 & (1.99) & 11.85 & $(2.43)$ & 1.45 & $(0.79)$ \\
\hline Brassicasterol & 99.33 & $(0.09)$ & - & - & - & - & - & - \\
\hline Desmosterol & - & - & - & - & 1.89 & $(0.12)$ & - & - \\
\hline $\begin{array}{c}\text { Campesterol } \\
24\end{array}$ & - & - & - & - & 36.68 & $(1.56)$ & 88.92 & $(2.14)$ \\
\hline MeCholesterol & - & - & 6.61 & (1.94) & 36.72 & $(4.06)$ & 9.63 & $(1.35)$ \\
\hline Fucosterol & - & - & 37.26 & $(0.64)$ & 3.02 & $(1.8)$ & - & - \\
\hline Isofucosterol & - & - & 5.19 & $(0.7)$ & 5.08 & $(1.66)$ & - & - \\
\hline fg cell ${ }^{-1}$ & 83.71 & 7.68 & 103.39 & 13.22 & 58.46 & 4.71 & 330.31 & 108.67 \\
\hline
\end{tabular}

Table 2

\begin{tabular}{lccc}
\hline Initial values (spring) & Gonad & $\begin{array}{c}\text { Digestive } \\
\text { g. }\end{array}$ & Muscle
\end{tabular}


Protein $\left(\mathrm{mg} \mathrm{dwg}^{-1}\right)$

$408.0(38)$

$523.9(65)$

$843.9(67) \quad 705.5(05)$

Carbohydrate $\left(\mathrm{mg} \mathrm{dwg}^{-1}\right)$

$79.5(13)$

$93.7(7)$

$23.4(1)$

$17.2(1)$

Values after 6 weeks of conditioning

Isochrysis affinis galbana

Protein ( $\mathrm{mg} \mathrm{dwg}^{-1}$ )

Carbohydrate (mg dwg $\left.{ }^{-1}\right)$

Chaetoceros gracilis

Protein ( $\mathrm{mg} \mathrm{dwg}^{-1}$ )

Carbohydrate $\left(\mathrm{mg} \mathrm{dwg}^{-1}\right)$

Skeletonema marinoï

Protein (mg dwg ${ }^{-1}$ )

Carbohydrate (mg dwg ${ }^{-1}$ )

Tetraselmis suecica

Protein (mg dwg ${ }^{-1}$ )

Carbohydrate (mg dwg ${ }^{-1}$ )

\begin{tabular}{rrrr}
$528.7(37)$ & $581.2(103)$ & $724.6(141)$ & $540.6(177)$ \\
$79.1(12)$ & $125.4(16)$ & $17.9(5)$ & $9.6(3)$ \\
& & & \\
$347.4(23)$ & $445.5(12)$ & $696.7(39)$ & $657.8(61)$ \\
$122.4(15)$ & $109.9(6)$ & $26.6(2)$ & $14.9(1)$ \\
& & & \\
$393.5(22)$ & $454.1(22)$ & $697.3(21)$ & $722.8(50)$ \\
$141.2(15)$ & $123.1(5)$ & $22.4(4)$ & $16.5(1)$ \\
$447.6(26)$ & 614.33 & $659.6(57)$ & $643.3(42)$ \\
$116.4(4)$ & $116.1(14)$ & $22.5(5)$ & $17.6(2)$ \\
\hline
\end{tabular}

\section{Table 3}

\begin{tabular}{|c|c|c|c|c|c|c|c|c|c|c|}
\hline \multirow{3}{*}{ Fatty acid } & \multirow{2}{*}{\multicolumn{2}{|c|}{ Initial }} & \multicolumn{8}{|c|}{ Oyster diets } \\
\hline & & & \multicolumn{2}{|c|}{ Isochrysis affinis. galbana } & \multicolumn{2}{|c|}{ Chaetoceros gracilis } & \multicolumn{2}{|c|}{ Skeletonema marinoï } & \multicolumn{2}{|c|}{ Tetraselmis suecica } \\
\hline & $\begin{array}{l}\text { Mean absolute } \\
\text { contents } \\
\pm \text { S.D }\left(\mu \mathrm{g} \mathrm{mg}^{-1}\right)\end{array}$ & $\begin{array}{c}\text { Mean relative } \\
\text { content } \\
\pm \text { S.D }(\%) \\
\end{array}$ & $\begin{array}{c}\text { Mean absolute } \\
\text { contents } \\
\pm \text { S.D }\left(\mu \mathrm{g} \mathrm{mg}^{-1}\right)\end{array}$ & $\begin{array}{c}\text { Mean relative } \\
\text { content } \\
\pm \text { S.D }(\%) \\
\end{array}$ & $\begin{array}{c}\text { Mean absolute } \\
\text { contents } \\
\pm \mathrm{S} . \mathrm{D}\left(\mu \mathrm{g} \mathrm{m}^{-1}\right) \\
\end{array}$ & $\begin{array}{c}\text { Mean relative } \\
\text { content } \\
\pm \text { S.D }(\%) \\
\end{array}$ & $\begin{array}{c}\text { Mean absolute } \\
\text { contents } \\
\pm \text { S.D }\left(\mu \mathrm{mg}^{-1}\right) \\
\end{array}$ & $\begin{array}{c}\text { Mean relative } \\
\text { content } \\
\pm \text { S.D }(\%) \\
\end{array}$ & $\begin{array}{c}\text { Mean absolute } \\
\text { contents } \\
\pm \text { S.D }\left(\mu \mathrm{g} \mathrm{mg}^{-1}\right)\end{array}$ & $\begin{array}{c}\text { Mean relative } \\
\text { content } \\
\pm \text { S.D }(\%) \\
\end{array}$ \\
\hline $14: 0$ & $0.48 \pm 0.48$ & $2.16 \pm 1.25$ & $0.60 \pm 0.04$ & $2.83 \pm 0.33$ & $0.35 \pm 0.03$ & $2.40 \pm 0.31$ & $0.49 \pm 0.05$ & $3.23 \pm 0.13$ & $0.22 \pm 0.18$ & $1.24 \pm 0.39$ \\
\hline $16: 0$ & $3.26 \pm 2.17$ & $16.18 \pm 3.25$ & $3.24 \pm 0.23$ & $15.20 \pm 0.86$ & $2.29 \pm 0.03$ & $15.81 \pm 0.78$ & $2.18 \pm 0.23$ & $14.32 \pm 0.73$ & $3.40 \pm 3.04$ & $16.87 \pm 1.65$ \\
\hline 18:0 & $0.85 \pm 0.27$ & $4.67 \pm 0.56$ & $0.79 \pm 0.07$ & $3.71 \pm 0.21$ & $0.64 \pm 0.03$ & $4.40 \pm 0.05$ & $0.64 \pm 0.03$ & $4.24 \pm 0.34$ & $1.15 \pm 1.02$ & $5.67 \pm 0.36$ \\
\hline $16: 1(n-9)$ & $0.08 \pm 0.03$ & $0.47 \pm 0.25$ & $0.05 \pm 0.00$ & $0.24 \pm 0.02$ & $0.00 \pm 0.00$ & $0.00 \pm 0.00$ & $0.03 \pm 0.00$ & $0.16 \pm 0.01$ & $0.08 \pm 0.04$ & $0.72 \pm 0.67$ \\
\hline $16: 1(n-7)$ & $0.56 \pm 0.58$ & $2.50 \pm 1.55$ & $0.27 \pm 0.01$ & $1.28 \pm 0.10$ & $0.82 \pm 0.08$ & $5.64 \pm 0.74$ & $0.44 \pm 0.06$ & $2.90 \pm 0.12$ & $0.28 \pm 0.23$ & $1.41 \pm 0.16$ \\
\hline $18: 1(n-9)$ & $0.51 \pm 0.33$ & $2.57 \pm 0.49$ & $1.12 \pm 0.04$ & $5.27 \pm 0.21$ & $0.15 \pm 0.00$ & $1.06 \pm 0.01$ & $0.18 \pm 0.01$ & $1.16 \pm 0.08$ & $0.65 \pm 0.56$ & $3.30 \pm 0.36$ \\
\hline $18: 1(n-7)$ & $0.42 \pm 0.40$ & $1.91 \pm 1.00$ & $0.32 \pm 0.01$ & $1.51 \pm 0.06$ & $0.50 \pm 0.01$ & $3.43 \pm 0.06$ & $0.50 \pm 0.08$ & $3.29 \pm 0.15$ & $0.26 \pm 0.22$ & $1.34 \pm 0.16$ \\
\hline
\end{tabular}




\begin{tabular}{|c|c|c|c|c|c|c|c|c|c|c|}
\hline $20: 1(n-9)$ & $0.10 \pm 0.01$ & $0.56 \pm 0.20$ & $0.27 \pm 0.04$ & $1.29 \pm 0.13$ & $0.04 \pm 0.01$ & $0.28 \pm 0.03$ & $0.05 \pm 0.01$ & $0.30 \pm 0.05$ & $0.22 \pm 0.22$ & $1.03 \pm 0.10$ \\
\hline $20: 1(n-7)$ & $0.92 \pm 0.35$ & $4.94 \pm 0.47$ & $0.81 \pm 0.10$ & $3.80 \pm 0.30$ & $0.81 \pm 0.05$ & $5.55 \pm 0.13$ & $1.17 \pm 0.15$ & $7.69 \pm 0.34$ & $1.18 \pm 1.10$ & $5.48 \pm 0.16$ \\
\hline $16: 3(n-6)$ & $0.02 \pm 0.02$ & $0.11 \pm 0.06$ & $0.00 \pm 0.00$ & $0.01 \pm 0.01$ & $0.00 \pm 0.00$ & $0.02 \pm 0.03$ & $0.00 \pm 0.00$ & $0.00 \pm 0.00$ & $0.01 \pm 0.01$ & $0.03 \pm 0.02$ \\
\hline $16: 4(n-3)$ & $0.03 \pm 0.01$ & $0.16 \pm 0.05$ & $0.02 \pm 0.00$ & $0.08 \pm 0.01$ & $0.01 \pm 0.00$ & $0.09 \pm 0.01$ & $0.01 \pm 0.01$ & $0.06 \pm 0.03$ & $0.03 \pm 0.02$ & $0.14 \pm 0.05$ \\
\hline $18: 2(n-6)$ & $0.19 \pm 0.17$ & $0.90 \pm 0.41$ & $1.11 \pm 0.04$ & $5.21 \pm 0.30$ & $0.07 \pm 0.01$ & $0.50 \pm 0.07$ & $0.30 \pm 0.03$ & $2.00 \pm 0.15$ & $0.15 \pm 0.13$ & $0.75 \pm 0.10$ \\
\hline $18: 3(n-3)$ & $0.31 \pm 0.32$ & $1.39 \pm 0.86$ & $0.31 \pm 0.02$ & $1.44 \pm 0.15$ & $0.04 \pm 0.00$ & $0.25 \pm 0.03$ & $0.07 \pm 0.01$ & $0.45 \pm 0.04$ & $0.22 \pm 0.20$ & $1.12 \pm 0.15$ \\
\hline $20: 4(n-3)$ & $0.09 \pm 0.09$ & $0.41 \pm 0.23$ & $0.05 \pm 0.01$ & $0.23 \pm 0.03$ & $0.03 \pm 0.00$ & $0.21 \pm 0.02$ & $0.02 \pm 0.01$ & $0.14 \pm 0.02$ & $0.06 \pm 0.06$ & $0.30 \pm 0.02$ \\
\hline $20: 5(n-3)$ & $2.93 \pm 1.94$ & $14.60 \pm 2.94$ & $1.16 \pm 0.19$ & $5.43 \pm 0.54$ & $2.51 \pm 0.02$ & $17.29 \pm 0.49$ & $2.65 \pm 0.44$ & $17.27 \pm 0.82$ & $2.61 \pm 2.43$ & $12.16 \pm 0.33$ \\
\hline $22: 4(n-6)$ & $0.08 \pm 0.02$ & $0.51 \pm 0.25$ & $0.15 \pm 0.02$ & $0.70 \pm 0.05$ & $0.08 \pm 0.00$ & $0.57 \pm 0.03$ & $0.07 \pm 0.01$ & $0.43 \pm 0.05$ & $0.16 \pm 0.14$ & $0.78 \pm 0.05$ \\
\hline $22: 5(n-6)$ & $0.10 \pm 0.01$ & $0.56 \pm 0.19$ & $0.91 \pm 0.06$ & $4.29 \pm 0.04$ & $0.06 \pm 0.00$ & $0.42 \pm 0.01$ & $0.04 \pm 0.00$ & $0.24 \pm 0.01$ & $0.14 \pm 0.13$ & $0.67 \pm 0.04$ \\
\hline $22: 5(n-3)$ & $0.22 \pm 0.03$ & $1.29 \pm 0.35$ & $0.17 \pm 0.02$ & $0.82 \pm 0.06$ & $0.21 \pm 0.01$ & $1.44 \pm 0.14$ & $0.19 \pm 0.05$ & $1.23 \pm 0.23$ & $0.34 \pm 0.31$ & $1.65 \pm 0.05$ \\
\hline $22: 6(n-3)$ & $2.50 \pm 0.83$ & $13.58 \pm 1.42$ & $3.19 \pm 0.21$ & $14.96 \pm 0.70$ & $1.03 \pm 0.01$ & $7.13 \pm 0.18$ & $1.14 \pm 0.13$ & $7.48 \pm 0.39$ & $2.54 \pm 2.44$ & $11.85 \pm 0.64$ \\
\hline TO.MONO & $3.13 \pm 1.89$ & $15.84 \pm 2.21$ & $3.59 \pm 0.17$ & $16.84 \pm 0.30$ & $2.85 \pm 0.04$ & $19.63 \pm 0.49$ & $2.87 \pm 0.35$ & $18.78 \pm 0.06$ & $3.38 \pm 3.03$ & $16.47 \pm 0.77$ \\
\hline TO.(n-9) & $0.77 \pm 0.38$ & $3.99 \pm 0.38$ & $1.53 \pm 0.12$ & $7.17 \pm 0.41$ & $0.34 \pm 0.00$ & $2.33 \pm 0.07$ & $0.27 \pm 0.03$ & $1.79 \pm 0.06$ & $0.99 \pm 0.87$ & $5.17 \pm 1.00$ \\
\hline TO.(n-7) & $1.91 \pm 1.33$ & $9.37 \pm 2.21$ & $1.41 \pm 0.11$ & $6.61 \pm 0.31$ & $2.13 \pm 0.01$ & $14.64 \pm 0.65$ & $2.13 \pm 0.28$ & $13.90 \pm 0.16$ & $1.72 \pm 1.55$ & $8.27 \pm 0.27$ \\
\hline TO.POLY & $9.22 \pm 4.15$ & $48.60 \pm 0.13$ & $10.35 \pm 0.69$ & $48.53 \pm 0.61$ & $6.41 \pm 0.24$ & $44.11 \pm 0.04$ & $7.00 \pm 0.90$ & $45.77 \pm 0.30$ & $10.15 \pm 9.53$ & $47.48 \pm 0.80$ \\
\hline TO.(n-6) & $1.00 \pm 0.34$ & $5.46 \pm 0.60$ & $3.08 \pm 0.16$ & $14.46 \pm 0.18$ & $0.86 \pm 0.05$ & $5.94 \pm 0.09$ & $0.91 \pm 0.08$ & $5.96 \pm 0.24$ & $1.37 \pm 1.25$ & $6.38 \pm 0.39$ \\
\hline TO.(n-3) & $6.89 \pm 3.79$ & $35.36 \pm 3.30$ & $5.74 \pm 0.46$ & $26.92 \pm 1.03$ & $4.23 \pm 0.05$ & $29.11 \pm 0.78$ & $4.48 \pm 0.68$ & $29.25 \pm 1.29$ & $6.51 \pm 6.10$ & $30.88 \pm 1.15$ \\
\hline$(n-3) /(n-6)$ & $6.58 \pm 1.37$ & $6.58 \pm 1.37$ & $1.86 \pm 0.09$ & $1.86 \pm 0.09$ & $4.90 \pm 0.20$ & $4.90 \pm 0.20$ & $4.91 \pm 0.36$ & $4.91 \pm 0.36$ & $4.86 \pm 0.48$ & $4.86 \pm 0.48$ \\
\hline $22: 6 / 20: 5$ & $0.97 \pm 0.27$ & $0.97 \pm 0.27$ & $2.77 \pm 0.30$ & $2.77 \pm 0.30$ & $0.41 \pm 0.00$ & $0.41 \pm 0.00$ & $0.43 \pm 0.03$ & $0.43 \pm 0.03$ & $0.98 \pm 0.07$ & $0.98 \pm 0.07$ \\
\hline TOTAL & $18.98 \pm 8.59$ & $100.00 \pm 0.00$ & $21.32 \pm 1.33$ & $100.00 \pm 0.00$ & $14.53 \pm 0.55$ & $100.0 \pm 0.00$ & $15.29 \pm 1.87$ & $100.00 \pm 0.00$ & $21.16 \pm 19.58$ & $100.00 \pm 0.00$ \\
\hline
\end{tabular}

Table 4

\begin{tabular}{|c|c|c|c|c|c|c|c|c|c|c|}
\hline \multirow{3}{*}{ Fatty acid } & \multirow{2}{*}{\multicolumn{2}{|c|}{ Initial }} & \multicolumn{8}{|c|}{ Oyster diets } \\
\hline & & & \multicolumn{2}{|c|}{ Isochrysis affinis. galbana } & \multicolumn{2}{|c|}{ Chaetoceros gracilis } & \multicolumn{2}{|c|}{ Skeletonema marinoï } & \multicolumn{2}{|c|}{ Tetraselmis suecica } \\
\hline & $\begin{array}{c}\text { Mean absolute } \\
\text { contents } \\
\pm \text { S.D }\left(\mu \mathrm{g} \mathrm{mg}^{-1}\right)\end{array}$ & $\begin{array}{c}\text { Mean relative } \\
\text { content } \\
\pm \text { S.D }(\%)\end{array}$ & $\begin{array}{l}\text { Mean absolute } \\
\text { contents } \\
\pm \text { S.D }\left(\mu \mathrm{gg} \mathrm{m}^{-1}\right)\end{array}$ & $\begin{array}{c}\text { Mean relative } \\
\text { content } \\
\pm \text { S.D }(\%)\end{array}$ & $\begin{array}{l}\text { Mean absolute } \\
\text { contents } \\
\pm \mathrm{S} . \mathrm{D}\left(\mu \mathrm{mg}^{-1}\right)\end{array}$ & $\begin{array}{c}\text { Mean relative } \\
\text { content } \\
\pm \text { S.D }(\%)\end{array}$ & $\begin{array}{l}\text { Mean absolute } \\
\text { contents } \\
\pm \text { S.D }\left(\mu \mathrm{mg} \mathrm{m}^{-1}\right)\end{array}$ & $\begin{array}{c}\text { Mean relative } \\
\text { content } \\
\pm \text { S.D }(\%)\end{array}$ & $\begin{array}{l}\text { Mean absolute } \\
\text { contents } \\
\pm \text { S.D }\left(\mu \mathrm{mg}^{-1}\right)\end{array}$ & $\begin{array}{c}\text { Mean relative } \\
\text { content } \\
\pm \text { S.D (\%) }\end{array}$ \\
\hline $14: 0$ & $0.17 \pm 0.02$ & $1.09 \pm 0.29$ & $0.57 \pm 0.15$ & $2.61 \pm 0.35$ & $0.97 \pm 0.91$ & $3.24 \pm 1.43$ & $0.49 \pm 0.01$ & $3.25 \pm 0.14$ & $0.14 \pm 0.04$ & $0.70 \pm 0.11$ \\
\hline $16: 0$ & $2.23 \pm 0.09$ & $14.28 \pm 2.35$ & $3.19 \pm 0.38$ & $14.76 \pm 0.94$ & $4.11 \pm 2.53$ & $15.64 \pm 0.15$ & $1.69 \pm 0.14$ & $11.05 \pm 0.73$ & $2.95 \pm 0.77$ & $14.99 \pm 0.46$ \\
\hline 18:0 & $0.93 \pm 0.07$ & $5.90 \pm 0.48$ & $1.03 \pm 0.21$ & $4.71 \pm 0.22$ & $0.93 \pm 0.22$ & $4.06 \pm 1.70$ & $0.80 \pm 0.05$ & $5.25 \pm 0.24$ & $1.16 \pm 0.33$ & $5.85 \pm 0.28$ \\
\hline $16: 1(n-9)$ & $0.04 \pm 0.01$ & $0.27 \pm 0.08$ & $0.06 \pm 0.03$ & $0.25 \pm 0.09$ & $0.01 \pm 0.02$ & $0.10 \pm 0.14$ & $0.02 \pm 0.00$ & $0.13 \pm 0.02$ & $0.07 \pm 0.03$ & $0.37 \pm 0.11$ \\
\hline $16: 1(n-7)$ & $0.21 \pm 0.01$ & $1.36 \pm 0.27$ & $0.22 \pm 0.06$ & $1.02 \pm 0.11$ & $2.40 \pm 2.52$ & $7.59 \pm 4.81$ & $0.41 \pm 0.02$ & $2.67 \pm 0.22$ & $0.22 \pm 0.06$ & $1.14 \pm 0.02$ \\
\hline 18:1(n-9) & $0.30 \pm 0.01$ & $1.95 \pm 0.33$ & $0.95 \pm 0.22$ & $4.32 \pm 0.28$ & $0.24 \pm 0.21$ & $0.80 \pm 0.31$ & $0.05 \pm 0.08$ & $0.32 \pm 0.55$ & $0.76 \pm 0.20$ & $3.85 \pm 0.27$ \\
\hline $18: 1(\mathrm{n}-7)$ & $0.18 \pm 0.02$ & $1.14 \pm 0.08$ & $0.31 \pm 0.07$ & $1.43 \pm 0.07$ & $1.53 \pm 1.48$ & $5.04 \pm 2.48$ & $0.49 \pm 0.03$ & $3.19 \pm 0.21$ & $0.26 \pm 0.06$ & $1.32 \pm 0.04$ \\
\hline $20: 1(n-9)$ & $0.10 \pm 0.00$ & $0.63 \pm 0.07$ & $0.25 \pm 0.04$ & $1.16 \pm 0.03$ & $0.06 \pm 0.04$ & $0.21 \pm 0.01$ & $0.03 \pm 0.00$ & $0.21 \pm 0.03$ & $0.29 \pm 0.14$ & $1.43 \pm 0.34$ \\
\hline $20: 1(n-7)$ & $0.80 \pm 0.08$ & $5.04 \pm 0.23$ & $0.81 \pm 0.13$ & $3.70 \pm 0.08$ & $1.07 \pm 0.71$ & $4.00 \pm 0.21$ & $0.89 \pm 0.07$ & $5.82 \pm 0.35$ & $1.01 \pm 0.30$ & $5.11 \pm 0.39$ \\
\hline $16: 3(n-6)$ & $0.01 \pm 0.01$ & $0.09 \pm 0.04$ & $0.00 \pm 0.00$ & $0.00 \pm 0.00$ & $0.00 \pm 0.00$ & $0.00 \pm 0.00$ & $0.00 \pm 0.00$ & $0.00 \pm 0.00$ & $0.02 \pm 0.00$ & $0.08 \pm 0.02$ \\
\hline
\end{tabular}




\begin{tabular}{|c|c|c|c|c|c|c|c|c|c|c|}
\hline $16: 4(n-3)$ & $0.03 \pm 0.00$ & $0.19 \pm 0.03$ & $0.02 \pm 0.01$ & $0.09 \pm 0.01$ & $0.05 \pm 0.05$ & $0.19 \pm 0.06$ & $0.01 \pm 0.00$ & $0.07 \pm 0.01$ & $0.03 \pm 0.01$ & $0.14 \pm 0.01$ \\
\hline $18: 2(n-6)$ & $0.08 \pm 0.01$ & $0.52 \pm 0.05$ & $0.99 \pm 0.20$ & $4.54 \pm 0.29$ & $0.15 \pm 0.14$ & $0.50 \pm 0.22$ & $0.22 \pm 0.00$ & $1.42 \pm 0.02$ & $0.15 \pm 0.03$ & $0.78 \pm 0.03$ \\
\hline $18: 3(n-3)$ & $0.12 \pm 0.00$ & $0.79 \pm 0.12$ & $0.31 \pm 0.07$ & $1.44 \pm 0.14$ & $0.13 \pm 0.13$ & $0.40 \pm 0.26$ & $0.05 \pm 0.00$ & $0.35 \pm 0.01$ & $0.28 \pm 0.07$ & $1.45 \pm 0.11$ \\
\hline $20: 4(n-3)$ & $0.05 \pm 0.01$ & $0.34 \pm 0.01$ & $0.05 \pm 0.00$ & $0.25 \pm 0.03$ & $0.09 \pm 0.09$ & $0.27 \pm 0.17$ & $0.02 \pm 0.00$ & $0.12 \pm 0.01$ & $0.05 \pm 0.01$ & $0.26 \pm 0.01$ \\
\hline $20: 5(n-3)$ & $2.04 \pm 0.64$ & $12.63 \pm 2.36$ & $0.96 \pm 0.16$ & $4.44 \pm 0.60$ & $6.06 \pm 5.28$ & $20.75 \pm 7.09$ & $2.70 \pm 0.11$ & $17.72 \pm 0.95$ & $2.17 \pm 0.62$ & $11.00 \pm 0.38$ \\
\hline $22: 4(n-6)$ & $0.09 \pm 0.02$ & $0.54 \pm 0.05$ & $0.12 \pm 0.02$ & $0.57 \pm 0.03$ & $0.04 \pm 0.01$ & $0.23 \pm 0.19$ & $0.04 \pm 0.00$ & $0.25 \pm 0.02$ & $0.14 \pm 0.04$ & $0.72 \pm 0.02$ \\
\hline $22: 5(n-6)$ & $0.09 \pm 0.02$ & $0.57 \pm 0.07$ & $1.07 \pm 0.17$ & $4.92 \pm 0.05$ & $0.05 \pm 0.01$ & $0.24 \pm 0.12$ & $0.03 \pm 0.00$ & $0.19 \pm 0.01$ & $0.18 \pm 0.03$ & $0.92 \pm 0.10$ \\
\hline $22: 5(n-3)$ & $0.25 \pm 0.07$ & $1.56 \pm 0.20$ & $0.15 \pm 0.02$ & $0.68 \pm 0.07$ & $0.18 \pm 0.03$ & $0.78 \pm 0.35$ & $0.13 \pm 0.01$ & $0.88 \pm 0.03$ & $0.30 \pm 0.09$ & $1.53 \pm 0.06$ \\
\hline $22: 6(n-3)$ & $2.29 \pm 0.77$ & $14.20 \pm 2.96$ & $3.43 \pm 0.42$ & $15.82 \pm 0.71$ & $1.48 \pm 0.94$ & $5.57 \pm 0.08$ & $1.05 \pm 0.05$ & $6.89 \pm 0.32$ & $2.06 \pm 0.61$ & $10.39 \pm 0.52$ \\
\hline TO.MONO & $2.06 \pm 0.14$ & $13.11 \pm 1.14$ & $3.24 \pm 0.68$ & $14.83 \pm 0.60$ & $6.08 \pm 4.93$ & $21.38 \pm 5.40$ & $2.38 \pm 0.05$ & $15.59 \pm 0.13$ & $3.21 \pm 0.69$ & $16.41 \pm 0.75$ \\
\hline TO.(n-9) & $0.48 \pm 0.02$ & $3.05 \pm 0.50$ & $1.30 \pm 0.27$ & $5.96 \pm 0.28$ & $0.32 \pm 0.23$ & $1.18 \pm 0.14$ & $0.13 \pm 0.07$ & $0.85 \pm 0.52$ & $1.16 \pm 0.37$ & $5.89 \pm 0.59$ \\
\hline TO.(n-7) & $1.19 \pm 0.09$ & $7.55 \pm 0.57$ & $1.36 \pm 0.26$ & $6.21 \pm 0.16$ & $5.04 \pm 4.75$ & $16.74 \pm 7.58$ & $1.79 \pm 0.04$ & $11.75 \pm 0.10$ & $1.49 \pm 0.41$ & $7.57 \pm 0.39$ \\
\hline TO.POLY & $7.64 \pm 1.83$ & $47.75 \pm 4.95$ & $11.21 \pm 1.66$ & $51.63 \pm 1.08$ & $11.90 \pm 8.25$ & $43.87 \pm 3.97$ & $7.05 \pm 0.07$ & $46.30 \pm 0.90$ & $9.29 \pm 2.60$ & $47.09 \pm 1.42$ \\
\hline TO.(n-6) & $0.83 \pm 0.20$ & $5.19 \pm 0.55$ & $3.31 \pm 0.56$ & $15.20 \pm 0.02$ & $1.25 \pm 0.86$ & $4.63 \pm 0.37$ & $0.78 \pm 0.03$ & $5.10 \pm 0.11$ & $1.42 \pm 0.38$ & $7.20 \pm 0.27$ \\
\hline TO.(n-3) & $5.21 \pm 1.59$ & $32.33 \pm 5.78$ & $6.01 \pm 0.76$ & $27.72 \pm 1.18$ & $8.71 \pm 7.05$ & $30.64 \pm 7.67$ & $4.34 \pm 0.14$ & $28.50 \pm 1.28$ & $5.59 \pm 1.61$ & $28.30 \pm 1.07$ \\
\hline$(n-3) /(n-6)$ & $6.20 \pm 0.49$ & $6.20 \pm 0.49$ & $1.82 \pm 0.08$ & $1.82 \pm 0.08$ & $6.57 \pm 1.13$ & $6.57 \pm 1.13$ & $5.60 \pm 0.37$ & $5.60 \pm 0.37$ & $3.93 \pm 0.18$ & $3.93 \pm 0.18$ \\
\hline $22: 6 / 20: 5$ & $1.12 \pm 0.03$ & $1.12 \pm 0.03$ & $3.60 \pm 0.41$ & $3.60 \pm 0.41$ & $0.28 \pm 0.09$ & $0.28 \pm 0.09$ & $0.39 \pm 0.01$ & $0.39 \pm 0.01$ & $0.94 \pm 0.02$ & $0.94 \pm 0.02$ \\
\hline TOTAL & $15.84 \pm 2.32$ & $100.00 \pm 0.00$ & $21.77 \pm 3.68$ & $100.00 \pm 0.00$ & $26.38 \pm 16.42$ & $100.00 \pm 0.00$ & $15.24 \pm 0.38$ & $100.00 \pm 0.00$ & $19.64 \pm 4.92$ & $100.00 \pm 0.00$ \\
\hline
\end{tabular}

\section{Table 5}

\begin{tabular}{|c|c|c|c|c|c|c|c|c|c|c|}
\hline \multirow{3}{*}{ Fatty acid } & \multirow{2}{*}{\multicolumn{2}{|c|}{ Initial }} & \multicolumn{8}{|c|}{ Oyster diets } \\
\hline & & & \multicolumn{2}{|c|}{ Isochrysis affinis. galbana } & \multicolumn{2}{|c|}{ Chaetoceros gracilis } & \multicolumn{2}{|c|}{ Skeletonema marinoï } & \multicolumn{2}{|c|}{ Tetraselmis suecica } \\
\hline & $\begin{array}{l}\text { Mean absolute } \\
\text { contents } \\
\pm \mathrm{S} . \mathrm{D}\left(\mu \mathrm{g} \mathrm{m}^{-1}\right)\end{array}$ & $\begin{array}{c}\text { Mean relative } \\
\text { content } \\
\pm \text { S.D (\%) }\end{array}$ & $\begin{array}{l}\text { Mean absolute } \\
\text { contents } \\
\pm \text { S.D }\left(\mu \mathrm{gg} \mathrm{m}^{-1}\right)\end{array}$ & $\begin{array}{c}\text { Mean relative } \\
\text { content } \\
\pm \text { S.D }(\%)\end{array}$ & $\begin{array}{l}\text { Mean absolute } \\
\text { contents } \\
\pm \mathrm{S} . \mathrm{D}\left(\mu \mathrm{gg} \mathrm{m}^{-1}\right)\end{array}$ & $\begin{array}{c}\text { Mean relative } \\
\text { content } \\
\pm \text { S.D }(\%)\end{array}$ & $\begin{array}{l}\text { Mean absolute } \\
\text { contents } \\
\pm \text { S.D }\left(\mu \mathrm{mg}^{-1}\right)\end{array}$ & $\begin{array}{c}\text { Mean relative } \\
\text { content } \\
\pm \text { S.D }(\%)\end{array}$ & $\begin{array}{l}\text { Mean absolute } \\
\text { contents } \\
\pm \text { S.D }\left(\mu \mathrm{g} \mathrm{mg}^{-1}\right)\end{array}$ & $\begin{array}{c}\text { Mean relative } \\
\text { content } \\
\pm \text { S.D }(\%)\end{array}$ \\
\hline $14: 0$ & $0.07 \pm 0.01$ & $0.78 \pm 0.05$ & $0.13 \pm 0.04$ & $1.60 \pm 0.13$ & $0.14 \pm 0.02$ & $1.61 \pm 0.22$ & $0.14 \pm 0.09$ & $1.62 \pm 0.55$ & $0.08 \pm 0.02$ & $0.90 \pm 0.30$ \\
\hline $16: 0$ & $0.84 \pm 0.09$ & $9.34 \pm 0.15$ & $1.15 \pm 0.45$ & $13.79 \pm 2.47$ & $1.35 \pm 0.25$ & $14.35 \pm 1.17$ & $1.06 \pm 0.69$ & $14.94 \pm 0.94$ & $1.21 \pm 0.08$ & $14.07 \pm 0.94$ \\
\hline 18:0 & $0.45 \pm 0.06$ & $5.04 \pm 0.26$ & $0.45 \pm 0.15$ & $5.36 \pm 0.15$ & $0.59 \pm 0.07$ & $6.33 \pm 0.23$ & $0.47 \pm 0.31$ & $6.69 \pm 0.44$ & $0.66 \pm 0.07$ & $7.93 \pm 0.93$ \\
\hline $16: 1(n-9)$ & $0.02 \pm 0.01$ & $0.20 \pm 0.10$ & $0.00 \pm 0.00$ & $0.00 \pm 0.00$ & $0.01 \pm 0.01$ & $0.07 \pm 0.13$ & $0.00 \pm 0.01$ & $0.06 \pm 0.10$ & $0.00 \pm 0.00$ & $0.00 \pm 0.00$ \\
\hline $16: 1(n-7)$ & $0.08 \pm 0.01$ & $0.87 \pm 0.05$ & $0.12 \pm 0.04$ & $1.41 \pm 0.12$ & $0.15 \pm 0.13$ & $1.62 \pm 1.11$ & $0.08 \pm 0.11$ & $1.00 \pm 0.86$ & $0.11 \pm 0.03$ & $1.16 \pm 0.33$ \\
\hline $18: 1(n-9)$ & $0.17 \pm 0.01$ & $1.87 \pm 0.14$ & $0.23 \pm 0.07$ & $2.85 \pm 0.44$ & $0.11 \pm 0.01$ & $1.29 \pm 0.21$ & $0.11 \pm 0.08$ & $1.60 \pm 0.43$ & $0.18 \pm 0.02$ & $2.12 \pm 0.29$ \\
\hline $18: 1(n-7)$ & $0.08 \pm 0.01$ & $0.91 \pm 0.02$ & $0.10 \pm 0.05$ & $1.19 \pm 0.26$ & $0.25 \pm 0.03$ & $2.57 \pm 0.23$ & $0.15 \pm 0.11$ & $1.82 \pm 0.70$ & $0.06 \pm 0.05$ & $0.49 \pm 0.70$ \\
\hline $20: 1(n-9)$ & $0.07 \pm 0.01$ & $0.81 \pm 0.04$ & $0.16 \pm 0.04$ & $1.89 \pm 0.22$ & $0.09 \pm 0.02$ & $1.01 \pm 0.23$ & $0.09 \pm 0.06$ & $1.42 \pm 0.27$ & $0.13 \pm 0.02$ & $1.48 \pm 0.21$ \\
\hline $20: 1(n-7)$ & $0.54 \pm 0.07$ & $6.04 \pm 0.24$ & $0.55 \pm 0.18$ & $6.58 \pm 0.24$ & $0.81 \pm 0.06$ & $8.76 \pm 0.24$ & $0.66 \pm 0.43$ & $8.87 \pm 0.97$ & $0.68 \pm 0.03$ & $7.84 \pm 0.57$ \\
\hline $16: 3(n-6)$ & $0.00 \pm 0.00$ & $0.02 \pm 0.02$ & $0.00 \pm 0.00$ & $0.00 \pm 0.00$ & $0.00 \pm 0.00$ & $0.00 \pm 0.00$ & $0.00 \pm 0.00$ & $0.00 \pm 0.00$ & $0.00 \pm 0.00$ & $0.00 \pm 0.00$ \\
\hline $16: 4(n-3)$ & $0.01 \pm 0.00$ & $0.12 \pm 0.00$ & $0.00 \pm 0.00$ & $0.02 \pm 0.04$ & $0.00 \pm 0.00$ & $0.01 \pm 0.03$ & $0.00 \pm 0.00$ & $0.07 \pm 0.06$ & $0.01 \pm 0.01$ & $0.04 \pm 0.06$ \\
\hline $18: 2(n-6)$ & $0.05 \pm 0.00$ & $0.54 \pm 0.02$ & $0.18 \pm 0.05$ & $2.14 \pm 0.08$ & $0.04 \pm 0.00$ & $0.52 \pm 0.27$ & $0.06 \pm 0.04$ & $0.70 \pm 0.27$ & $0.04 \pm 0.00$ & $0.49 \pm 0.06$ \\
\hline
\end{tabular}




\begin{tabular}{|c|c|c|c|c|c|c|c|c|c|c|}
\hline $18: 3(n-3)$ & $0.07 \pm 0.00$ & $0.78 \pm 0.06$ & $0.08 \pm 0.03$ & $0.91 \pm 0.15$ & $0.04 \pm 0.00$ & $0.45 \pm 0.07$ & $0.04 \pm 0.03$ & $0.61 \pm 0.09$ & $0.06 \pm 0.01$ & $0.73 \pm 0.12$ \\
\hline $20: 4(n-3)$ & $0.02 \pm 0.00$ & $0.27 \pm 0.03$ & $0.02 \pm 0.01$ & $0.26 \pm 0.07$ & $0.02 \pm 0.00$ & $0.20 \pm 0.02$ & $0.02 \pm 0.01$ & $0.25 \pm 0.05$ & $0.02 \pm 0.01$ & $0.25 \pm 0.07$ \\
\hline $20: 5(n-3)$ & $1.32 \pm 0.17$ & $14.74 \pm 0.23$ & $0.95 \pm 0.31$ & $11.46 \pm 0.71$ & $1.67 \pm 0.14$ & $17.62 \pm 0.62$ & $1.21 \pm 0.80$ & $16.62 \pm 1.21$ & $1.36 \pm 0.05$ & $15.98 \pm 1.04$ \\
\hline $22: 4(n-6)$ & $0.04 \pm 0.00$ & $0.49 \pm 0.01$ & $0.07 \pm 0.02$ & $0.87 \pm 0.17$ & $0.07 \pm 0.01$ & $0.71 \pm 0.06$ & $0.05 \pm 0.03$ & $0.69 \pm 0.11$ & $0.08 \pm 0.00$ & $0.92 \pm 0.02$ \\
\hline $22: 5(n-6)$ & $0.06 \pm 0.01$ & $0.69 \pm 0.02$ & $0.18 \pm 0.05$ & $2.23 \pm 0.27$ & $0.06 \pm 0.01$ & $0.65 \pm 0.04$ & $0.04 \pm 0.03$ & $0.65 \pm 0.10$ & $0.07 \pm 0.00$ & $0.78 \pm 0.00$ \\
\hline $22: 5(n-3)$ & $0.19 \pm 0.01$ & $2.08 \pm 0.09$ & $0.16 \pm 0.05$ & $1.97 \pm 0.18$ & $0.18 \pm 0.02$ & $1.95 \pm 0.06$ & $0.14 \pm 0.09$ & $2.10 \pm 0.23$ & $0.20 \pm 0.01$ & $2.30 \pm 0.03$ \\
\hline $22: 6(n-3)$ & $1.55 \pm 0.19$ & $17.27 \pm 0.14$ & $1.53 \pm 0.49$ & $18.44 \pm 1.04$ & $1.37 \pm 0.13$ & $14.77 \pm 0.37$ & $1.10 \pm 0.75$ & $15.86 \pm 1.17$ & $1.53 \pm 0.02$ & $17.94 \pm 0.59$ \\
\hline TOMONO & $1.16 \pm 0.13$ & $12.89 \pm 0.31$ & $1.33 \pm 0.41$ & $15.97 \pm 0.09$ & $1.64 \pm 0.19$ & $17.74 \pm 1.21$ & $1.24 \pm 0.88$ & $17.05 \pm 1.21$ & $1.35 \pm 0.19$ & $14.86 \pm 1.94$ \\
\hline TO.(n-9) & $0.27 \pm 0.02$ & $3.06 \pm 0.20$ & $0.41 \pm 0.12$ & $5.01 \pm 0.71$ & $0.24 \pm 0.04$ & $2.73 \pm 0.44$ & $0.23 \pm 0.16$ & $3.37 \pm 0.62$ & $0.33 \pm 0.04$ & $3.66 \pm 0.45$ \\
\hline TO.(n-7) & $0.70 \pm 0.08$ & $7.82 \pm 0.21$ & $0.77 \pm 0.27$ & $9.18 \pm 0.31$ & $1.21 \pm 0.19$ & $12.95 \pm 1.03$ & $0.89 \pm 0.63$ & $11.72 \pm 1.71$ & $0.85 \pm 0.09$ & $9.50 \pm 0.94$ \\
\hline TO.POLY & $4.49 \pm 0.53$ & $49.93 \pm 0.27$ & $5.02 \pm 1.54$ & $60.44 \pm 3.05$ & $5.45 \pm 0.42$ & $58.03 \pm 2.64$ & $4.06 \pm 2.81$ & $56.38 \pm 2.90$ & $5.16 \pm 0.11$ & $60.07 \pm 0.73$ \\
\hline TO.(n-6) & $0.47 \pm 0.06$ & $5.23 \pm 0.06$ & $0.78 \pm 0.23$ & $9.41 \pm 0.60$ & $0.58 \pm 0.06$ & $6.13 \pm 0.15$ & $0.43 \pm 0.29$ & $6.07 \pm 0.18$ & $0.56 \pm 0.02$ & $6.52 \pm 0.17$ \\
\hline TO.(n-3) & $3.32 \pm 0.39$ & $36.92 \pm 0.18$ & $3.54 \pm 1.07$ & $42.67 \pm 2.25$ & $4.04 \pm 0.30$ & $42.69 \pm 2.54$ & $2.91 \pm 2.03$ & $40.73 \pm 3.53$ & $3.88 \pm 0.08$ & $45.43 \pm 1.82$ \\
\hline$(n-3) /(n-6)$ & $7.06 \pm 0.10$ & $7.06 \pm 0.10$ & $4.54 \pm 0.06$ & $4.54 \pm 0.06$ & $7.03 \pm 0.36$ & $6.96 \pm 0.33$ & $6.63 \pm 0.36$ & $6.71 \pm 0.42$ & $6.98 \pm 0.32$ & $6.98 \pm 0.46$ \\
\hline $22: 6 / 20: 5$ & $1.17 \pm 0.02$ & $1.17 \pm 0.02$ & $1.61 \pm 0.02$ & $1.61 \pm 0.02$ & $0.82 \pm 0.02$ & $0.84 \pm 0.05$ & $0.89 \pm 0.06$ & $0.96 \pm 0.14$ & $1.12 \pm 0.03$ & $1.12 \pm 0.04$ \\
\hline TOTAL & $8.98 \pm 1.02$ & $100.00 \pm 0.00$ & $8.31 \pm 2.59$ & $100.00 \pm 0.00$ & $9.35 \pm 0.85$ & $100.00 \pm 0.00$ & $7.15 \pm 4.84$ & $100.00 \pm 0.00$ & $8.66 \pm 0.31$ & $100.00 \pm 0.00$ \\
\hline
\end{tabular}

Table 6

Fatty acid Initial

Isochrysis affinis. galbana

Oyster diets

\begin{tabular}{|c|c|c|c|c|c|c|c|c|c|c|}
\hline & $\begin{array}{l}\text { Mean absolute } \\
\text { contents } \\
\pm \text { S.D }\left(\mu \mathrm{mg} \mathrm{m}^{-1}\right)\end{array}$ & $\begin{array}{c}\text { Mean relative } \\
\text { content } \\
\pm \text { S.D }(\%)\end{array}$ & $\begin{array}{l}\text { Mean absolute } \\
\text { contents } \\
\pm \text { S.D }\left(\mu \mathrm{g} \mathrm{mg}^{-1}\right)\end{array}$ & $\begin{array}{c}\text { Mean relative } \\
\text { content } \\
\pm \text { S.D }(\%)\end{array}$ & $\begin{array}{l}\text { Mean absolute } \\
\text { contents } \\
\pm \text { S.D }\left(\mu \mathrm{g} \mathrm{mg}^{-1}\right)\end{array}$ & $\begin{array}{c}\text { Mean relative } \\
\text { content } \\
\pm \text { S.D }(\%)\end{array}$ & $\begin{array}{l}\text { Mean absolute } \\
\text { contents } \\
\pm \text { S.D }\left(\mu \mathrm{g} \mathrm{mg}^{-1}\right)\end{array}$ & $\begin{array}{c}\text { Mean relative } \\
\text { content } \\
\pm \text { S.D }(\%)\end{array}$ & $\begin{array}{l}\text { Mean absolute } \\
\text { contents } \\
\pm \text { S.D }\left(\mu \mathrm{mg} \mathrm{m}^{-1}\right)\end{array}$ & $\begin{array}{c}\text { Mean relative } \\
\text { content } \\
\pm \text { S.D (\%) }\end{array}$ \\
\hline $14: 0$ & $0.09 \pm 0.03$ & $0.63 \pm 0.20$ & $0.35 \pm 0.15$ & $1.80 \pm 0.18$ & $0.34 \pm 0.07$ & $1.60 \pm 0.25$ & $0.62 \pm 0.20$ & $1.52 \pm 0.95$ & $0.09 \pm 0.01$ & $0.51 \pm 0.06$ \\
\hline $16: 0$ & $1.20 \pm 0.32$ & $8.44 \pm 0.49$ & $3.18 \pm 1.25$ & $16.35 \pm 1.02$ & $4.20 \pm 0.60$ & $17.15 \pm 2.36$ & $4.69 \pm 1.75$ & $15.03 \pm 1.66$ & $2.80 \pm 0.02$ & $15.40 \pm 0.30$ \\
\hline 18:0 & $0.62 \pm 0.19$ & $4.36 \pm 0.04$ & $0.75 \pm 0.27$ & $3.93 \pm 0.21$ & $1.01 \pm 0.26$ & $4.25 \pm 0.14$ & $1.27 \pm 0.42$ & $4.67 \pm 0.97$ & $1.01 \pm 0.09$ & $5.22 \pm 0.37$ \\
\hline $16: 1(n-9)$ & $0.02 \pm 0.02$ & $0.14 \pm 0.13$ & $0.00 \pm 0.00$ & $0.00 \pm 0.00$ & $0.00 \pm 0.00$ & $0.00 \pm 0.00$ & $0.00 \pm 0.00$ & $0.00 \pm 0.00$ & $0.00 \pm 0.00$ & $0.00 \pm 0.00$ \\
\hline $16: 1(n-7)$ & $0.13 \pm 0.03$ & $0.91 \pm 0.12$ & $0.26 \pm 0.07$ & $1.39 \pm 0.20$ & $0.67 \pm 0.10$ & $2.42 \pm 0.84$ & $0.50 \pm 0.16$ & $1.14 \pm 0.99$ & $0.00 \pm 0.00$ & $0.00 \pm 0.00$ \\
\hline $18: 1(n-9)$ & $0.18 \pm 0.04$ & $1.30 \pm 0.14$ & $0.70 \pm 0.29$ & $3.61 \pm 0.44$ & $0.14 \pm 0.02$ & $0.58 \pm 0.05$ & $0.12 \pm 0.10$ & $0.95 \pm 1.02$ & $0.46 \pm 0.11$ & $2.97 \pm 0.66$ \\
\hline $18: 1(n-7)$ & $0.09 \pm 0.03$ & $0.62 \pm 0.02$ & $0.26 \pm 0.10$ & $1.34 \pm 0.05$ & $0.73 \pm 0.20$ & $3.16 \pm 0.07$ & $0.94 \pm 0.27$ & $2.22 \pm 1.33$ & $0.16 \pm 0.04$ & $1.05 \pm 0.26$ \\
\hline $20: 1(n-9)$ & $0.10 \pm 0.03$ & $0.73 \pm 0.01$ & $0.30 \pm 0.11$ & $1.57 \pm 0.06$ & $0.31 \pm 0.22$ & $1.12 \pm 1.12$ & $0.27 \pm 0.22$ & $1.40 \pm 0.97$ & $0.28 \pm 0.03$ & $1.66 \pm 0.19$ \\
\hline $20: 1(n-7)$ & $0.79 \pm 0.23$ & $5.56 \pm 0.08$ & $0.90 \pm 0.30$ & $4.72 \pm 0.18$ & $1.53 \pm 0.41$ & $7.12 \pm 0.99$ & $2.49 \pm 0.77$ & $7.67 \pm 0.60$ & $1.30 \pm 0.04$ & $7.06 \pm 0.02$ \\
\hline $16: 3(n-6)$ & $0.01 \pm 0.01$ & $0.07 \pm 0.02$ & $0.00 \pm 0.00$ & $0.00 \pm 0.00$ & $0.00 \pm 0.00$ & $0.00 \pm 0.00$ & $0.00 \pm 0.00$ & $0.00 \pm 0.00$ & $0.00 \pm 0.00$ & $0.00 \pm 0.00$ \\
\hline $16: 4(n-3)$ & $0.01 \pm 0.01$ & $0.09 \pm 0.07$ & $0.00 \pm 0.00$ & $0.00 \pm 0.00$ & $0.00 \pm 0.00$ & $0.00 \pm 0.00$ & $0.00 \pm 0.00$ & $0.00 \pm 0.00$ & $0.00 \pm 0.00$ & $0.00 \pm 0.00$ \\
\hline $18: 2(n-6)$ & $0.03 \pm 0.01$ & $0.23 \pm 0.03$ & $0.66 \pm 0.29$ & $3.36 \pm 0.43$ & $0.05 \pm 0.01$ & $0.56 \pm 0.61$ & $0.38 \pm 0.15$ & $0.93 \pm 0.51$ & $0.08 \pm 0.02$ & $0.52 \pm 0.10$ \\
\hline $18: 3(n-3)$ & $0.04 \pm 0.01$ & $0.28 \pm 0.03$ & $0.11 \pm 0.04$ & $0.56 \pm 0.04$ & $0.02 \pm 0.00$ & $0.10 \pm 0.05$ & $0.05 \pm 0.01$ & $0.23 \pm 0.13$ & $0.09 \pm 0.03$ & $0.64 \pm 0.19$ \\
\hline $20: 4(n-3)$ & $0.01 \pm 0.00$ & $0.06 \pm 0.00$ & $0.01 \pm 0.00$ & $0.05 \pm 0.01$ & $0.01 \pm 0.00$ & $0.03 \pm 0.02$ & $0.01 \pm 0.00$ & $0.05 \pm 0.05$ & $0.00 \pm 0.00$ & $0.12 \pm 0.00$ \\
\hline
\end{tabular}




\begin{tabular}{|c|c|c|c|c|c|c|c|c|c|c|}
\hline $20: 5(n-3)$ & $1.48 \pm 0.40$ & $10.41 \pm 0.28$ & $0.89 \pm 0.23$ & $4.79 \pm 0.69$ & $3.66 \pm 0.80$ & $15.36 \pm 0.72$ & $4.61 \pm 1.49$ & $13.41 \pm 2.99$ & $1.80 \pm 0.13$ & $9.46 \pm 0.44$ \\
\hline $22: 4(n-6)$ & $0.05 \pm 0.09$ & $0.29 \pm 0.50$ & $0.21 \pm 0.07$ & $1.07 \pm 0.01$ & $0.18 \pm 0.04$ & $0.75 \pm 0.07$ & $0.07 \pm 0.12$ & $0.40 \pm 0.69$ & $0.21 \pm 0.02$ & $1.12 \pm 0.06$ \\
\hline $22: 5(n-6)$ & $0.05 \pm 0.07$ & $0.26 \pm 0.38$ & $1.07 \pm 0.46$ & $5.44 \pm 0.56$ & $0.12 \pm 0.02$ & $0.47 \pm 0.07$ & $0.05 \pm 0.06$ & $0.34 \pm 0.52$ & $0.18 \pm 0.00$ & $0.99 \pm 0.03$ \\
\hline $22: 5(n-3)$ & $0.23 \pm 0.05$ & $1.67 \pm 0.16$ & $0.17 \pm 0.05$ & $0.91 \pm 0.10$ & $0.31 \pm 0.05$ & $1.26 \pm 0.18$ & $0.33 \pm 0.09$ & $1.33 \pm 0.46$ & $0.32 \pm 0.04$ & $1.62 \pm 0.17$ \\
\hline $22: 6(n-3)$ & $2.14 \pm 0.54$ & $15.06 \pm 0.61$ & $3.27 \pm 1.21$ & $16.89 \pm 0.43$ & $1.82 \pm 0.32$ & $8.81 \pm 1.70$ & $3.19 \pm 0.89$ & $11.37 \pm 1.94$ & $2.35 \pm 0.30$ & $11.80 \pm 1.28$ \\
\hline TO.MONO & $1.73 \pm 0.49$ & $12.11 \pm 0.36$ & $2.88 \pm 1.04$ & $14.96 \pm 0.54$ & $4.02 \pm 1.07$ & $16.91 \pm 0.55$ & $5.34 \pm 0.92$ & $16.88 \pm 3.69$ & $2.65 \pm 0.18$ & $15.34 \pm 1.37$ \\
\hline TO.(n-9) & $0.33 \pm 0.09$ & $2.29 \pm 0.25$ & $1.08 \pm 0.44$ & $5.56 \pm 0.54$ & $0.74 \pm 0.12$ & $2.58 \pm 1.60$ & $0.44 \pm 0.26$ & $2.49 \pm 1.60$ & $0.75 \pm 0.14$ & $4.65 \pm 0.84$ \\
\hline TO.(n-7) & $1.01 \pm 0.28$ & $7.10 \pm 0.11$ & $1.43 \pm 0.46$ & $7.49 \pm 0.37$ & $2.93 \pm 0.71$ & $12.71 \pm 0.20$ & $3.93 \pm 1.18$ & $11.04 \pm 2.87$ & $1.47 \pm 0.01$ & $8.14 \pm 0.27$ \\
\hline TO.POLY & $6.58 \pm 1.97$ & $46.02 \pm 0.52$ & $11.32 \pm 4.04$ & $58.94 \pm 2.70$ & $13.05 \pm 3.86$ & $57.28 \pm 3.52$ & $17.51 \pm 5.58$ & $56.88 \pm 4.91$ & $11.10 \pm 0.63$ & $58.83 \pm 1.87$ \\
\hline TO.(n-6) & $0.88 \pm 0.36$ & $6.06 \pm 0.70$ & $3.32 \pm 1.31$ & $17.03 \pm 0.91$ & $2.08 \pm 0.56$ & $8.95 \pm 0.17$ & $2.42 \pm 0.78$ & $8.08 \pm 1.48$ & $1.83 \pm 0.00$ & $10.11 \pm 0.25$ \\
\hline TO.(n-3) & $4.03 \pm 1.11$ & $28.33 \pm 0.45$ & $5.60 \pm 1.96$ & $29.48 \pm 3.54$ & $7.33 \pm 2.15$ & $31.73 \pm 1.38$ & $9.55 \pm 3.09$ & $31.73 \pm 3.66$ & $6.23 \pm 0.60$ & $32.05 \pm 2.39$ \\
\hline$(n-3) /(n-6)$ & $4.72 \pm 0.58$ & $4.72 \pm 0.58$ & $1.74 \pm 0.28$ & $1.74 \pm 0.28$ & $3.51 \pm 0.09$ & $3.55 \pm 0.09$ & $3.95 \pm 0.30$ & $3.96 \pm 0.29$ & $3.40 \pm 0.33$ & $3.17 \pm 0.33$ \\
\hline $22: 6 / 20: 5$ & $1.45 \pm 0.05$ & $1.45 \pm 0.05$ & $3.57 \pm 0.51$ & $3.57 \pm 0.51$ & $0.50 \pm 0.02$ & $0.58 \pm 0.14$ & $0.70 \pm 0.04$ & $0.90 \pm 0.39$ & $1.30 \pm 0.07$ & $1.25 \pm 0.07$ \\
\hline TOTAL & $14.28 \pm 4.15$ & $100.00 \pm 0.00$ & $19.27 \pm 6.95$ & $100.00 \pm 0.00$ & $23.32 \pm 5.76$ & $100.0 \pm 0.00$ & $30.62 \pm 8.35$ & $100.00 \pm 0.00$ & $18.46 \pm 0.47$ & $100.00 \pm 0.00$ \\
\hline
\end{tabular}

Table 7

\begin{tabular}{|c|c|c|c|c|c|}
\hline \multirow[b]{2}{*}{ Gonad } & Control & I. aff. galbana & C. gracilis & S. marinoï & T. suecica \\
\hline & & & & & \\
\hline $\begin{array}{r}\text { Brassicasterol } \\
\text { Cholesterol }\end{array}$ & $\begin{array}{ll}18.51 & (0.65) \\
31.67 & (0.49)\end{array}$ & $\begin{array}{ll}40.24 & (2.78) \\
27.88 & (2.48)\end{array}$ & $\begin{array}{rr}8.02 & (5.05) \\
47.43 & (3.17)\end{array}$ & $\begin{array}{ll}10.22 & (0.84) \\
29.39 & (0.61)\end{array}$ & $\begin{array}{ll}17.96 & (0.50) \\
33.20 & (0.96)\end{array}$ \\
\hline
\end{tabular}




$\begin{array}{rrrrrrrrrrr}\text { Campesterol } & 3.13 & (0.09) & 2.40 & (0.09) & 5.52 & (6.37) & 17.53 & (1.86) & 3.76 & (0.27) \\ \text { 24MeCholesterol } & 15.21 & (0.62) & 9.09 & (0.88) & 8.08 & (5.39) & 16.05 & (1.79) & 14.51 & (0.66) \\ \text { Fucosterol } & 1.05 & (0.11) & 0.50 & (0.06) & 8.37 & (2.85) & 0.82 & (0.14) & 0.86 & (0.16)\end{array}$

Digestive gland

$\begin{array}{rrlrlrlrlrr}\text { Brassicasterol } & 18.39 & (0.92) & 44.97 & (7.72) & 8.58 & (0.92) & 11.35 & (9.47) & 16.08 & (0.45) \\ \text { Cholesterol } & 30.91 & (0.34) & 26.30 & (3.42) & 49.19 & (1.68) & 25.47 & (3.17) & 32.04 & (1.10) \\ \text { Campesterol } & 3.36 & (0.08) & 2.39 & (0.21) & 1.57 & (0.08) & 22.36 & (2.16) & 6.03 & (0.52) \\ \text { 24MeCholesterol } & 14.66 & (0.56) & 9.47 & (0.93) & 10.37 & (0.44) & 16.69 & (1.12) & 16.80 & (0.66) \\ \text { Fucosterol } & 1.16 & (0.13) & 0.53 & (0.09) & 14.98 & (1.05) & 0.87 & (0.54) & 0.97 & (0.12)\end{array}$

Muscle

$\begin{array}{rrlrlrlrlrr}\text { Brassicasterol } & 18.90 & (0.17) & 28.11 & (0.43) & 16.97 & (0.95) & 16.20 & (0.31) & 19.54 & (0.49) \\ \text { Cholesterol } & 33.88 & (1.05) & 34.75 & (1.32) & 39.54 & (4.03) & 38.14 & (4.03) & 34.83 & (0.34) \\ \text { Campesterol } & 3.26 & (0.05) & 2.83 & (0.08) & 5.46 & (4.81) & 6.35 & (3.33) & 3.72 & (0.44) \\ \text { 24MeCholesterol } & 16.16 & (0.26) & 13.48 & (0.84) & 14.97 & (2.54) & 15.87 & (1.96) & 15.96 & (0.12) \\ \text { Fucosterol } & 0.93 & (0.04) & 0.61 & (0.14) & 2.90 & (2.13) & 2.37 & (2.35) & 0.74 & (0.09)\end{array}$

Gills

\begin{tabular}{rrrrrrrrrrr} 
Brassicasterol & 16.82 & $(0.10)$ & 36.34 & $(5.16)$ & 10.13 & $(0.42)$ & 9.90 & $(1.49)$ & 18.59 & $(0.41)$ \\
Cholesterol & 32.98 & $(0.56)$ & 24.06 & $(2.23)$ & 46.40 & $(0.74)$ & 27.11 & $(0.90)$ & 32.26 & $(0.66)$ \\
Campesterol & 3.15 & $(0.03)$ & 2.11 & $(0.33)$ & 1.67 & $(0.13)$ & 18.40 & $(2.98)$ & 3.92 & $(0.27)$ \\
24MeCholesterol & 15.46 & $(0.16)$ & 12.72 & $(0.58)$ & 11.18 & $(0.27)$ & 17.16 & $(0.10)$ & 14.43 & $(0.70)$ \\
Fucosterol & 1.12 & $(0.11)$ & 0.70 & $(0.18)$ & 11.26 & $(0.61)$ & 1.04 & $(0.16)$ & 0.99 & $(0.05)$ \\
\hline
\end{tabular}




\section{Figures}

Figure 1. Ingestion (mean \pm S.D.) of Ostrea edulis broodstock fed different microalgae species fed for six consecutive weeks. Values with different letters are significantly different $(p<0.05)$.

Figure 2. Absorption (mean \pm S.D.) and absorption efficiency (ae: \%) of Ostrea edulis broodstock fed different microalgae species for six consecutive weeks.

\section{Figure 1}

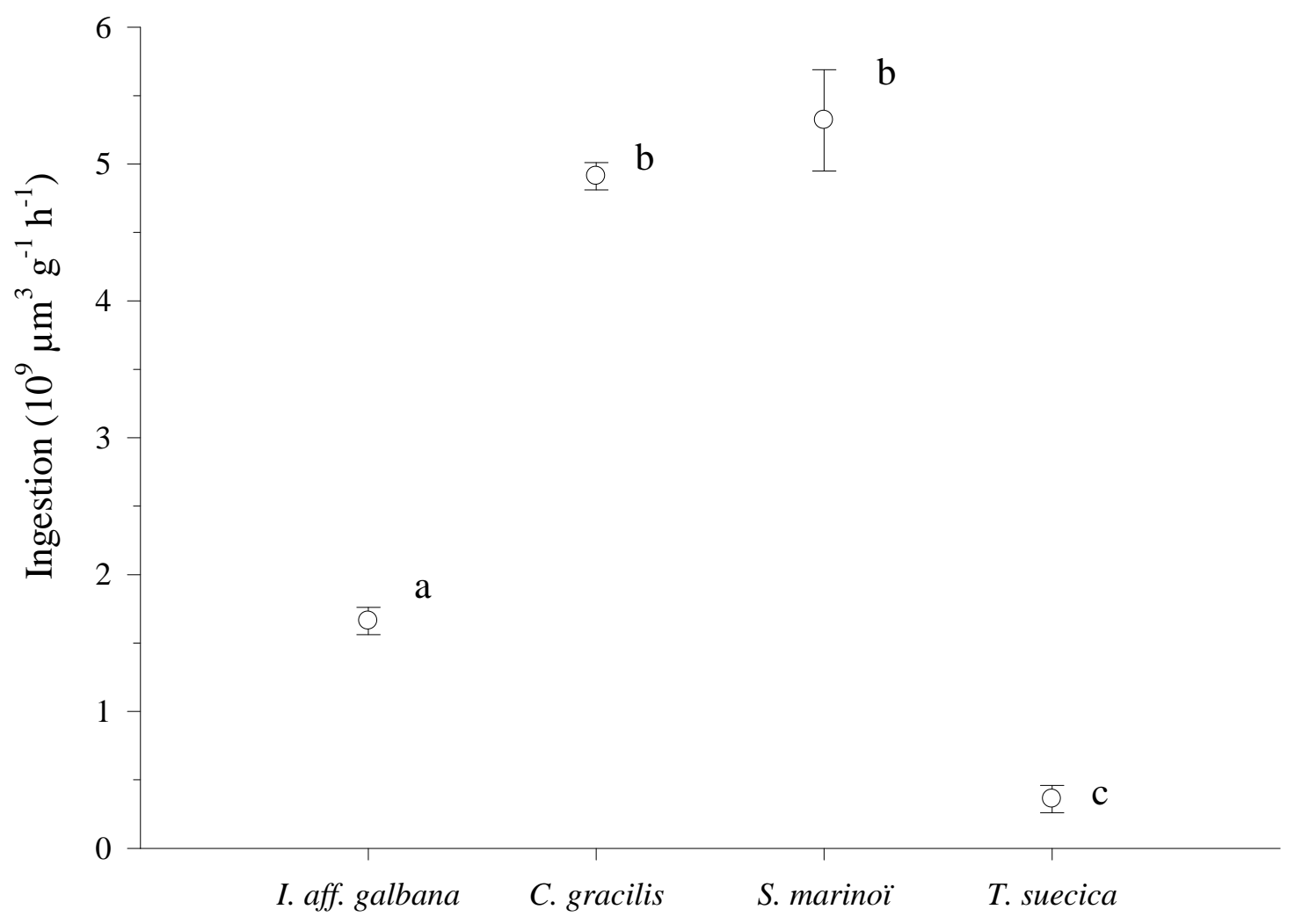


Figure 2

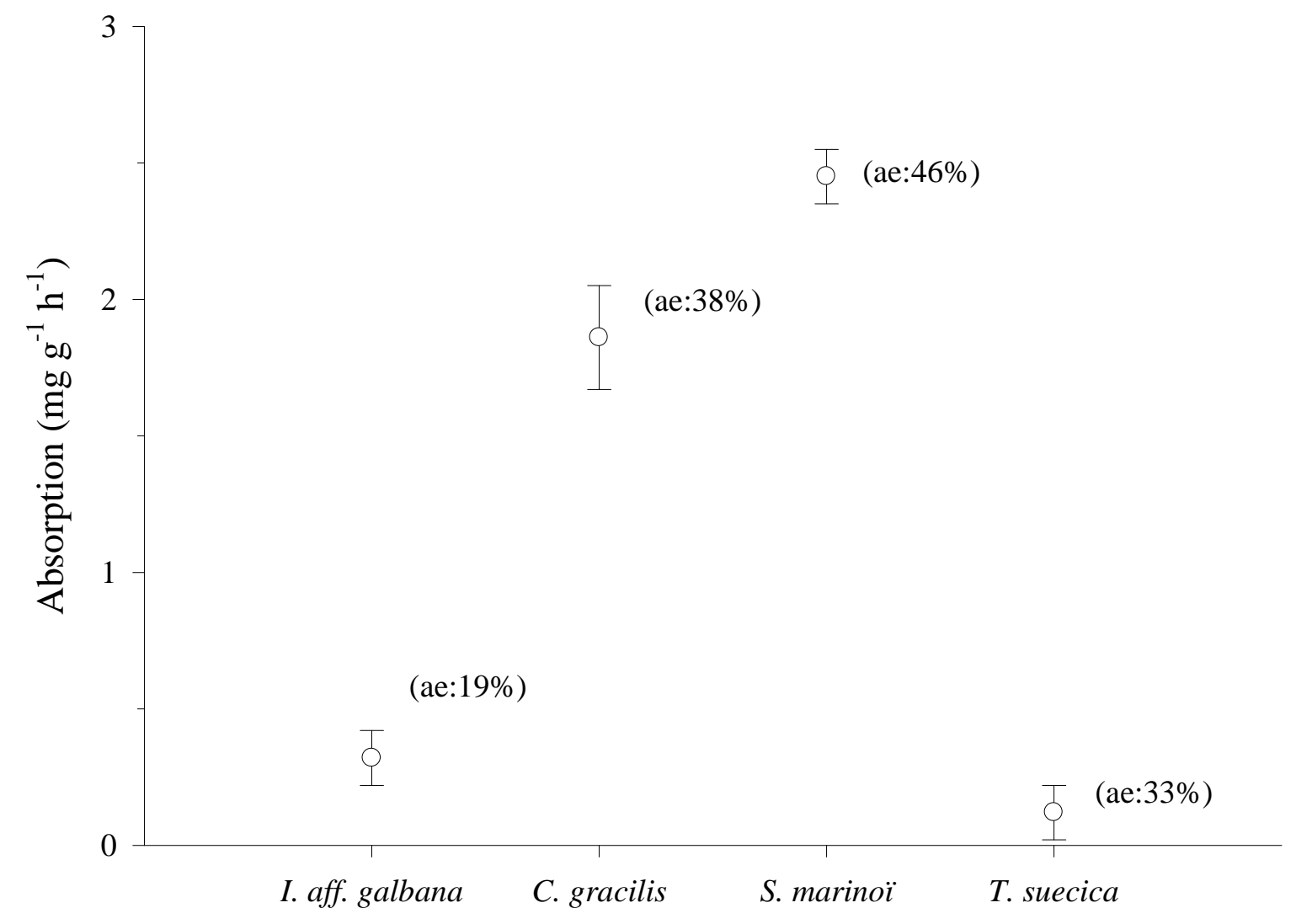

